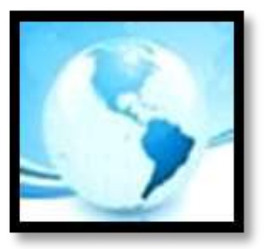

MALAYSIAN ONLINE JOURNAL OF

EDUCATIONAL MANAGEMENT

(MOJEM)

July 2020, VOLUME 8, ISSUE 3, 21-47

E-ISSN NO: $2289-4489$

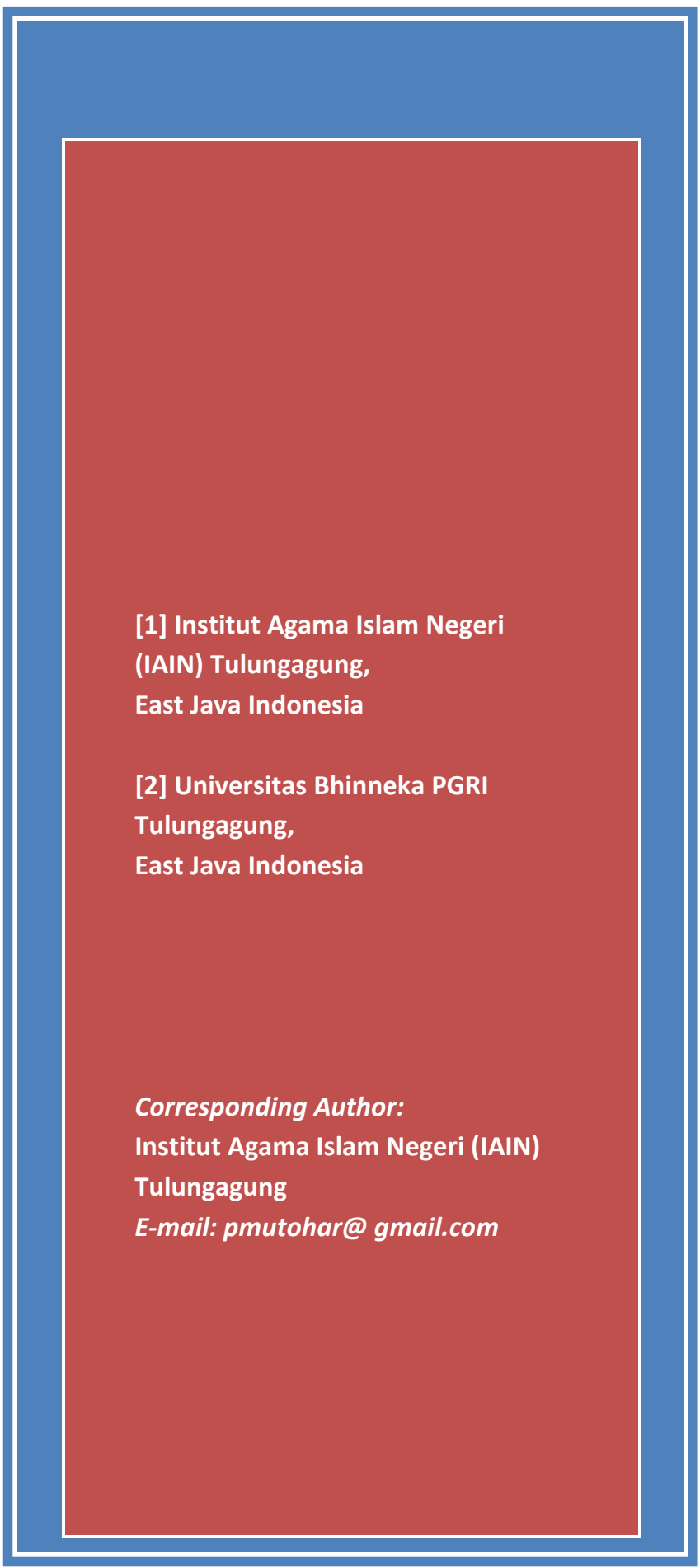

\section{THE EFFECTIVENESS OF MADRASAH: ANALYSIS OF MANAGERIAL SKILLS, LEARNING SUPERVISION, SCHOOL CULTURE, AND TEACHERS' PERFORMANCE}

Prim Masrokan Mutohar $(\mathrm{PhD})^{1}$ \& Hikmah Eva Trisnantari $(\mathrm{PhD})^{2}$

\begin{abstract}
The study of the effectiveness of madrasah has become the concern of Indonesia's education system to compete both nationally and internationally. This study belonged to a correlational research design to determine and measure the level of influence between variables, such as principals' managerial skills, supervision of learning, school culture, and teacher performance. This research was carried out at the Madrasah Aliyah Negeri (Islamic Senior High School) in Tulungagung, East Java, Indonesia. The research questionnaire was distributed to 213 teachers to dig out their perceptions on the principle's managerial skill, learning supervision, school culture, and teachers' performance. The distributed questionnaires were only responded and returned by 185 teachers. The data taken from 185 teachers were analyzed using the PLS SMART program. The result of the analysis revealed that the principals' managerial skills, the implementation of learning supervision, the formation of school culture, and teachers' performance affected the school's effectiveness. School effectiveness would be realized well if the school principals had good managerial skills to carry out the supervision of learning, create a strong school culture, and improve teacher performance effectively.
\end{abstract}

Keywords: Principals' Managerial Skills, Supervision of Learning, School Culture, Teacher Performance, School Effectiveness 


\section{MALAYSIAN ONLINE JOURNAL OF EDUCATIONAL MANAGEMENT (MOJEM)}

\section{INTRODUCTION}

Effective educational institutions are the concern of every educational stakeholder. This condition has become the driving force and enthusiasm of the management of educational institutions to make continuous improvements so that the institution is effective and in demand by the school user community. Effective and quality education can produce graduates who have the academic and non-academic competencies required by education stakeholders (Mutohar, 2013; Primayana, 2016). This condition is by the objectives of education in Indonesia to be able to educate the life of the nation and be able to fully develop Indonesian people. The purpose of this education is to deliver students to (1) have faith and devotion to God Almighty, (2) have a noble character, (3) have knowledge and skills, (4) be physically and mentally healthy, (5) have personality steady and independent, and (6) able to be responsible in the life of society and the nation (Indonesia, 2003).

Quality schools are effective schools. Effective schools can create learning experiences that are meaningful and relevant to the needs of students and the demands of the community so that all stakeholders support the educational policies that exist in the school (Kumara, 2018). Schools that can carry out education and learning processes that are by the needs and expectations of the community and produce outputs that have academic and non-academic competence. This competency is often referred to as the life-skills possessed by students after participating in all educational and learning activities in school. Students have the skills, strengths, and abilities acquired in learning life skills so that they can help in dealing with problems of daily life with a positive attitude, responsibility, and full of confidence (Behrani, 2016).

The main factors that are thought to be able to make a very large contribution in creating an effective school are the leadership and managerial skills possessed by the principal, the implementation of supervision of learning, school culture, and teacher performance. Leadership positively influences the quality of education (Ameen, Sandhu, \& Hussain, 2019). Effective schools have strong leadership support for principals in carrying out learning. Principal's leadership has a strong indirect effect on student achievement based on learning interactions and school culture (Wang, Demas, Quota, \& Prouty, 2019). The results also showed an influence between school quality culture and the principal's managerial competence (Maskur, Haryono, \& Hidayah, 2018).

Principal's managerial skills are thought to have a strong influence on organizational culture, teacher empowerment, and teacher performance in schools. The principal as a manager must be able to manage his school well to become a quality and effective school. The principal's leadership has a very important role in improving quality and effective schooling. This is consistent with the results of Likert's research which explains that leadership style is the main factor determining organizational success (Ameen et al., 2019; Fieldman \& Arnold, 1983; Majumdar, 2018). The principal's leadership style has a great influence on teacher performance (Wachira, Gitumu, \& Mbugua, 2017). The formation of teacher professionalism and continuous improvement in the quality of learning in schools is strongly influenced by the leadership of the principal (Amzat, 2017). The results of the study indicate that the principal's leadership is a key factor in realizing school success. Effective schools have a strong culture, requiring leaders who are experts in implementing school management (Maskur et al., 2018).

Teachers who have professional competence will show productive performance in all learning activities in schools. Teacher performance results are reflected in learning outcomes or achievements achieved by students in schools (DeRoche, 1985; Sergiovanni \& Starratt, 2006). Productive teacher performance will result in high learning achievement. High learning achievement is an indicator of school effectiveness. For this reason, teacher performance must be improved and improved through coaching and training, and there is an objective assessment of teacher performance to increase teacher productivity in the learning process (Gagne \& Briggs, 1974; Richey, 1973). The principal must be able to carry out the supervision of learning in holding professional teacher formation. The results showed there was a significant correlation between the supervision of the principal and the enthusiasm of the teacher's work (Murtiningsih, Kristiawan, \& Lian, 2019). Academic supervision of school principals and school culture has a simultaneous influence on the quality of teaching teachers (Mujiati, Suriansyah, 


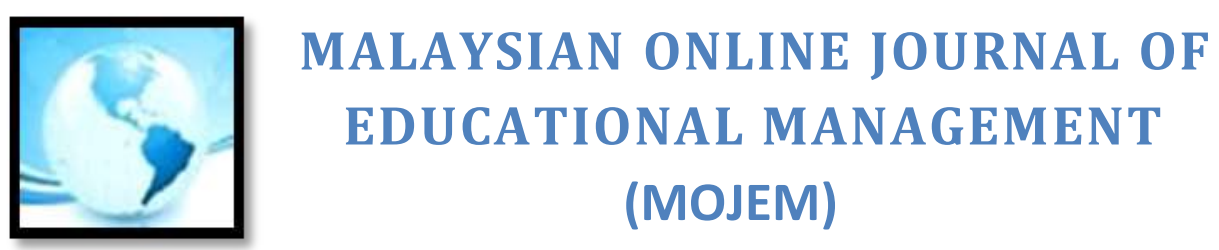

\& Effendi, 2019). These conditions must be supported by the quality school management, quality learning facilities and infrastructure, and ready to use, and the existence of high community participation in education (Motwani, \& Kumar, 1997; Naor, Goldstein, Linderman, \& Schroeder, 2008). Schools as educational institutions must have clear objectives, effective learning environments, physical resources or school facilities and infrastructure, Sufficient teacher resources, continuous professional development, teacher motivation, student motivation, effective supervision, and leadership (Syomwene, 2018).

School effectiveness can be achieved if there is effective performance. Effective teacher performance can be achieved if the teachers have high morale and are empowered as well as possible (Marks \& Louis, 1997). The working spirit of the teacher has implications for the success of the learning process, if the teacher has a good work spirit, students will be able to learn more easily and can achieve optimal learning outcomes (Kecapi, Maba, \& Paramartha, 2020; Smith, 2013). This research is driven by the ineffectiveness of reforms in the field of education as a result of efforts to improve the quality of education. This situation needs to be studied and researched to find out the cause and effect resulting from the decentralization of education and efforts to make educational institutions effective. This research is very appropriate to be carried out to find out the school's effectiveness in terms of the principal's managerial skills, supervision of learning, school culture, and teacher performance at the Islamic High School in Tulungagung, East Java, Indonesia. The research questions that will be examined in this study are:

1. Do the principals' managerial skills influence the implementation of instructional supervision?

2. Are the principals' managerial skills and implementation of instructional supervision have a direct and indirect influence on school culture?

3. Do the principals' managerial skills, supervision of learning, and school culture, directly and indirectly, influence teacher performance?

4. Are there principals' managerial skills, supervision of learning, school culture, and teacher performance that have an indirect influence on school effectiveness?

\section{THEORETICAL FOUNDATION}

\section{Madrasah in Indonesia}

Madrasah in terms of Arabic origin, which means school. Schools and madrasah have in common as a place for the learning process. At the beginning of its establishment, the madrasah had a curriculum that taught Islam to students as it was in Islamic boarding schools in Indonesia. However, in its development to date, madrasah implements the national curriculum and still maintain the religious curriculum as a characteristic of the madrasah. This is also reinforced by the results of Steenbrink's (1991) study of pesantren, madrasah, and schools explaining that madrasah are culturally having a curriculum that focuses more on religious aspects, whereas schools are general educational institutions with universal curricula influenced by the development of science and technology. The current condition of Madrasah develops while maintaining religious-based learning and adding a general curriculum that is the same as the school curriculum (Ikhwan, 2017). The existence of Madrasah is increasingly in demand by the community because it can teach general competencies and religious competencies as a basis in shaping behaviour and character in the education system in Indonesia (Nursikin, 2018).

\section{Principal's Managerial Skills}

Effective managerial skills need to be possessed by managers in running an organization to achieve its goals (Katz, 2009). Managerial skills can be obtained through relevant education and experience so that managers can do work effectively based on conceptual, human, and technical skills possessed by managers (Jones \& George, 2014). Technical skills are specific knowledge and techniques about a job, human skills include the ability possessed by someone in understanding, changing, leading, and controlling individual or group behaviours, while conceptual 


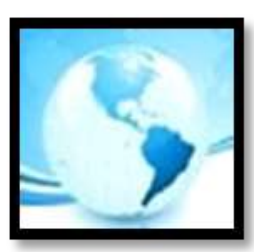

\section{MALAYSIAN ONLINE JOURNAL OF EDUCATIONAL MANAGEMENT (MOJEM)}

skills are the ability possessed by managers in analysing certain situations and conditions in the organization to differentiate the situation and be able to know the causes and consequences (Jones \& George, 2014; Katz, 2009; Mujtaba \& Kaifi, 2011). Conceptual skills possessed by managers are obtained through formal education, experience, and reflection (Jones \& George, 2014,). Managers can manage organizations well if they have the basic skills that must be possessed by the manger, organizational success is largely determined by the process of achieving goals (Jones \& George, 2014; Waddell, Devine, Jones, \& George, 2007).

The principal's managerial skills in carrying out daily tasks are inseparable from the leadership that he applies. Principals need to understand leadership effectiveness (Katz, 2009), approaches, leadership styles, and behaviours, managerial skills that must be possessed (Hersey, Blanchard, \& Johnson, 2007). This is because the success of a leader in carrying out the task depends on his leadership. The effectiveness of the management of arable fields in schools depends on the effectiveness of personal work, and the effectiveness of personal work is determined by the leadership and managerial skills possessed by the leader. The intended managerial skills are conceptual, technical, and human (Katz, 2009; Mukarromah, Mudjito, \& Purbaningrum, 2019; Robbin, 1990).

\section{Learning Supervision}

Another factor that could theoretically influence the effectiveness of educational institutions is the supervision of learning which is the duty and responsibility of the principal as a supervisor at school. The need for supervision of this teaching is based on the consideration, that there is no perfect education, including the education of prospective teachers, so the educational outcomes passed by prospective teachers are slow or fast will be left behind with the rapid development of science and technology. This explanation is by the opinion of Goodman and Adler (1985) which states that in this world there are no fully educated human beings, including teachers. Teachers as a key factor in education in schools must always anticipate these developments by keeping a distance so that they are not too far behind with the development of Science and Technology. In this regard, teachers need help to continue developing into professional teachers, assistance given to teachers to become professional teachers is referred to as learning supervision (Thair \& Treagust, 2003). In more detail, Neagley and Evans (1980), argues that increasing teacher knowledge can also be done through regular coaching through observation and class visits, carrying out clinical supervision, and supervisory meetings with teachers.

Supervision is a form of tangible assistance to teachers to improve teaching conditions has a very important meaning for the growth of teacher positions. One of the factors in supervision that has an important meaning in influencing success in coaching teachers is the orientation of appropriate supervision, which is carried out by the principals. The orientation of the principal's supervision is illustrated by the supervision approach used by the supervisor. In this connection, Glickman (1981) explains that supervisors in carrying out supervision can be carried out with a directive approach, a non-directive approach, and a collaborative approach.

The inadequate supervision of the principal can also be caused by the inability of the principal himself. Because the competency of the principal as a teacher builder is no different from the competency of teachers in general (Lovell \& Wiles, 1983). Therefore, Pont, Nusche, and Moorman (2008); Heyward, (2014) said that one of the obstacles in the implementation of supervision in Indonesia is due to the inadequate ability of supervisors (including school principals). In line with the foregoing, Mantja (2002) in her study of several research reports concluded that the principal had not carried out supervision properly.

\section{School Culture}

Schools have a culture that is by the characteristics that exist in schools, both related to values, norms, morals, and behaviours based on the school itself (Deal \& Peterson, 2016). This culture is related to the system of shared meaning by each member of the school organization in the form of values, norms, beliefs, traditions, and ways of thinking shared by all members of the school organization so that it distinguishes the organization from other 


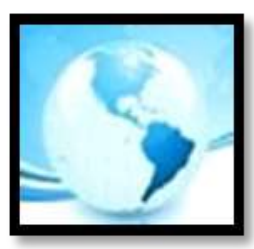

\section{MALAYSIAN ONLINE JOURNAL OF EDUCATIONAL MANAGEMENT (MOJEM)}

school organizations (Deal \& Peterson, 2016; Langton \& Robbins, 2007; Ouchi \& Cuchi, 1981; Owens, 1995; Waterman \& Peters, 1982). The system of shared meanings in the form of values, beliefs, and habits interacts with the formal structure of school organizations to produce norms of behaviours together (Smircich, 2017).

The existing school organizational culture is still weak and not yet competitive, especially in schools in the regions and rural areas. One of the factors causing the weak culture of school organization is the principal's leadership factor. Principals are less visionary, less able to set good examples, are less harmonious and communicative with subordinates, teachers are not fully empowered, and there are no efforts to develop teacher professionalism programmed by schools. This resulted in an uncompetitive teacher work culture. This condition must be improved by effectively enhancing school culture because school culture can help to achieve goals and make schools effective (Ali, Sharma, \& Zaman, 2017). School culture has an enormous influence on student discipline, school reform, school policy, teacher training, and educational leadership (Ohlson, Swanson, Adams-Manning, \& Byrd, 2016). School culture has a very strong influence in making school effective (Dogan, 2017). The research findings have proven that school culture needs to be improved and continuously improved to be able to create effective schools.

School culture is a force that can be used to work in making improvements and improving schools to be better (Redding \& Corbett, 2018). Schools with low achievement in them have a negative culture that contributes to school failure. Improvements can be made with cultural changes related to mindset, norms, and attitudes in behaviours to improve school quality. Strong school culture can improve the quality of schools in a sustainable manner (Lee \& Louis, 2019). To succeed in learning and teaching depends more on the culture of the school (Aasebø, Midtsundstad, \& Willbergh, 2017). The findings of the study explain that the culture of the school has a very big role in continuously improving the quality of schools to become effective and highly competitive schools.

\section{Teacher Performance}

Performance is a comparison between actual work results and work standards set by the organization (Dessler, 1997; Rivai, 2004). Performance is the authority and responsibility of a person or group of people to do work with a work ethic based on work ethics in achieving organizational goals (Mutohar \& Jani, 2020). In this case, Abdullah (2019) explained that the nature of performance is closely related to the work that has been achieved in carrying out his work. The results of this work are closely related to the quantity and quality that has been achieved by someone in carrying out their duties by the responsibilities given to him (Mangkunegara \& Prabu, 2004). Performance can be explained based on individual, team, and organizational reviews. Individual performance emphasizes more on its contribution by the status and role in the organization, team performance emphasizes the contribution generated in the form of overall teamwork, while organizational performance is related to the contribution of individual and team performance as a whole in the organizational system (Abdullah, 2019; Robbins \& Judge, 2003; Stolovich \& Keeps, 1992). Based on the description above, it can be explained that teacher performance is the work that has been achieved by the teacher both individually, in teams, and the school organization system in carrying out their duties and responsibilities as educators to achieve the goals, objectives, vision, and mission of the school.

Teacher performance as an educator is closely related to the ability of teachers to plan, to learn, implement learning, and evaluate student learning outcomes (Steinberg \& Garrett, 2016). The teacher has the duty and responsibility to carry out performance as a professional educator. To find out the teacher's professionalism, it is necessary to have a performance appraisal. This performance assessment is carried out systematically, periodically, and continuously in a transparent and accountable way to find out the actual work that has been carried out by the teacher in carrying out his duties as an educator (Kagema \& Irungu, 2018; Saleemi, 2011). Aguinis (2009) explains that performance appraisal is the process of identifying, measuring, and developing individual performance to suit organizational goals. Performance is the peak condition of three interrelated elements, namely: skills, efforts taken, external conditions (Klein \& Snell, 1994; Pichler, 2019). The performance results achieved by the teacher indicate the effectiveness of work behaviours that it implements. Teacher work 


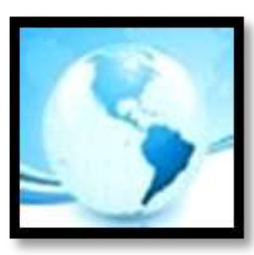

\section{MALAYSIAN ONLINE JOURNAL OF EDUCATIONAL MANAGEMENT (MOJEM)}

behaviours, in turn, can affect work results, work behaviours is influenced by internal and external factors. Internal factors are related to the skills and efforts of the teacher, and external factors include leadership, organizational culture, organizational climate, availability of materials and equipment, and so on.

\section{School effectiveness}

Effectiveness is achievement that is influenced by various internal and external processes. Internal factors are closely related to the roles of school administrators, principals, teamwork, pedagogical work organizations, and school culture. External factors are related to demographic transformation, school market dynamics, school policies, and educational programs (Bellei, Morawietz, Valenzuela, \& Vanni, 2019). School effectiveness is related to the level of concordance between the results achieved and the expected results based on the objectives, targets, intended outputs set by the school (Hartnell, Ou, \& Kinicki, 2011). Effective schools are schools that organize and utilize all the resources they have to ensure all students can learn based on the school curriculum (Newmann \& Wehlage, 1995). Effective schools are schools that are successful in learning and can adjust between quality and fairness standards. Quality is associated with high student learning outcomes, while justice is related to not distinguishing between social, economic, ethnic, gender, and so on. Effective schools can produce graduates by established quality standards (Granvik, Brolin, Almquist, \& Modin, 2018).

\section{THEORETICAL BACKGROUND AND HYPOTHESIS OF THE STUDY}

This study examines the effectiveness of schools in terms of principals' managerial skills, implementation of supervision of learning, teacher performance, and school culture. School effectiveness variables are developed based on a dynamic model of educational effectiveness (Creemers \& Kyriakides, 2006; Scheerens \& Creemers, 1989). To create an effective school, the principal's managerial abilities are needed which include conceptual abilities, technical abilities, and human abilities (Hersey et al., 2007; Katz, 2009; Robbin, 1990). Principal's managerial skills affect the effectiveness of the school (Mukarromah et al., 2019). Likewise in the implementation of supervision of learning (Magut, Chumba, \& Kindiki, 2017; McConnell, 2016; Ujiarto, Rusdarti, Rifai, \& Raharjo, 2017), the formation of school culture (Sabancı, Ahmet, Sönmez, \& Yılmaz, 2016), and in improving teacher performance (Mujhiyat, Abdullah, \& Akbar, 2018; Purba, Ambarita, \& Siagian, 2018).

Supervision of learning has an influence on teacher performance (Sihombing, Nasution, \& Sadalia, 2019; Sudarjat, Abdullah, \& Sunaryo, 2015) and school culture (Maskur et al., 2018; Mujiati et al., 2019) and so on. also in the formation of effective schools (Nwambam \& Eze, 2017). School culture has a very significant contribution to teacher performance (Mujhiyat et al., 2018). School culture also has a very strong influence in creating effective schools (Iroegbu \& Etudor-Eyo, 2016; Oke, 2016). Based on the results of previous studies and research, the influence model that occurs between the independent and dependent variables in this study can be explained in Figure 1 as follows: 


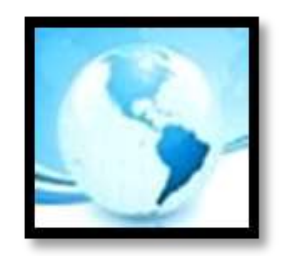

\section{MALAYSIAN ONLINE JOURNAL OF EDUCATIONAL MANAGEMENT (MOJEM)}

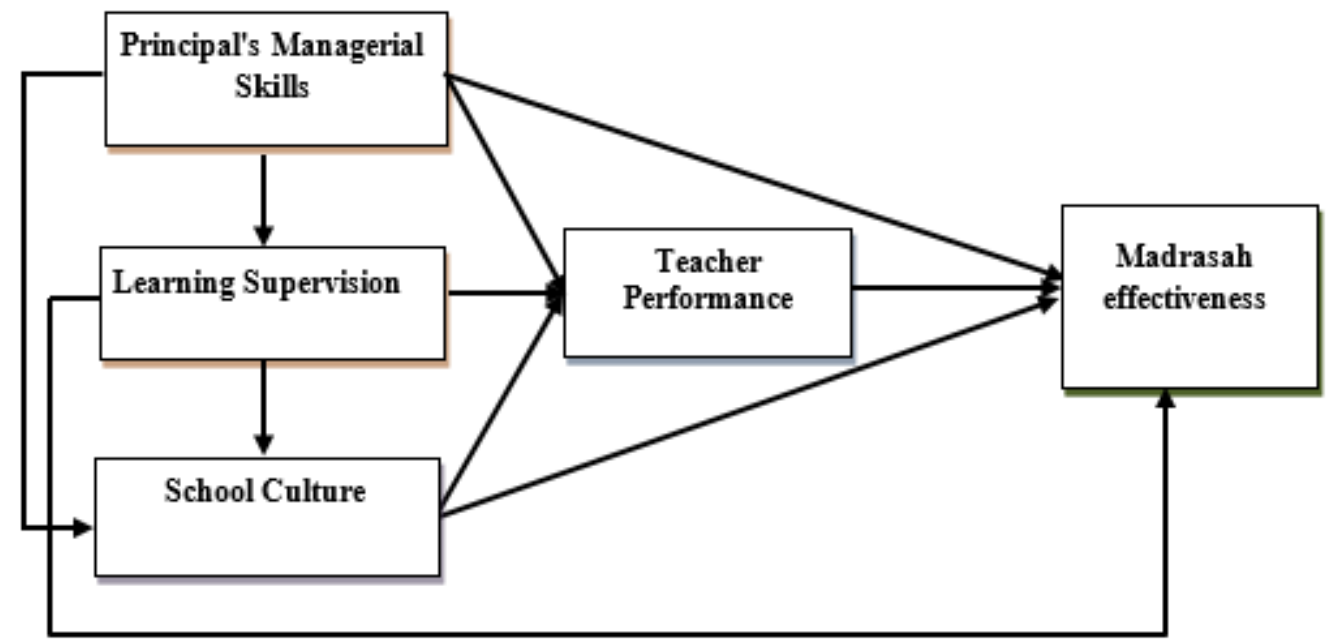

Figure 1. Conceptual Model of Relationship Between Research Variables

\section{METHODS}

\section{Research Design}

The purpose of this study was to identify the effects of research variables on principals' managerial skills, learning supervision, school culture, and teacher performance on school effectiveness using Structural Equation Modeling or SEM (Byrne, 2012; Ghozali, 2011). A quantitative approach to survey research design is used to examine and test the influence between research variables (Codd, 1970). Based on a review of the theory from various existing literature at this time, the model that combines the variables contained in this study has not been much studied before, and the suitability of this model is evaluated using SEM PLS (Ghozali, 2011).

\section{Research Population}

The population used as the object of this study were all teachers of the "Madrasah Aliah Negeri (MAN)" in Tulungagung Regency. MAN is an Islamic educational institution at the Senior High School level in Indonesia. The population of respondents in this study amounted to 213 teachers which can be seen in Table 1 below:

Table 1

Population of Teachers in MAN Tulungagung Regency, East Java, Indonesia

\begin{tabular}{lll}
\hline No & School & Total of Teachers \\
\hline 1 & MAN 1 Tulungagung & 75 \\
2 & MAN 2 Tulungagung & 78 \\
3 & MAN 3 Tulungagung & 60 \\
TOTAL & & 213 \\
\hline
\end{tabular}

This study used survey techniques by taking the entire population to be able to fill out a questionnaire in this study, so it does not take research samples. Questionnaires were distributed to 213 teachers in the Madrasah Aliah Negeri (MAN) Tulungagung. 


\section{Instrumentation}

The research instrument was a measuring instrument used to examine and examine the variables in this study. The research instrument on managerial skills consists of 12 questions that were developed and adapted based on Robbin's (1990) theory and opinion and Hersey et al. (2007). Research instruments about learning supervision are adapted and developed based on theories developed by Sergiovanni (1982). This instrument has 9 questions. The school culture instruments contained 15 questions. This instrument was adapted based on the results of research on school culture (Hargreaves, 1995; Owens, 1995; Robbins, \& Judge, 2003). Teacher performance instruments adapted from previous researches (Taylor \& Tyler, 2012; Jacob, Rockoff, Taylor, Lindy, \& Rosen, 2018). The instruments on school effectiveness totalled 16 questionnaires. This instrument was adapted and developed based on the results of research on school effectiveness carried out by previous researchers (Cerit \& Yıldırım, 2017; Kyriakides, Creemers, \& Charalambous, 2019; Reynolds, 2018).

Each question item in this research instrument used a choice of 5 Likert scales to find out respondents' opinions about perceptions and events known by respondents based on questions in this research instrument. According to ( 1 = Never, 2 = Rarely, 3 = Sometimes, 4 = Often, and 5 = Always). This study uses a questionnaire developed based on a 5-point Likert scale and contains 67 statement items that must be answered by respondents. This questionnaire must meet the elements of validity and reliability to be able to measure research variables that can be scientifically justified. To assess the outer model with SmartPLS in this study used the techniques of Discriminant Validity, Convergent Validity, Composite Reliability, and AVE.

This research questionnaire was tested for validity and reliability of 186 respondents in Madrasah Aliyah Negeri Tulungagung by using PLS-SEM structural equation modelling. Results on the validity and reliability of research instruments can be explained in Figure 2: 


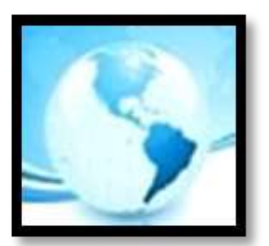

MALAYSIAN ONLINE JOURNAL OF

EDUCATIONAL MANAGEMENT

(MOJEM)

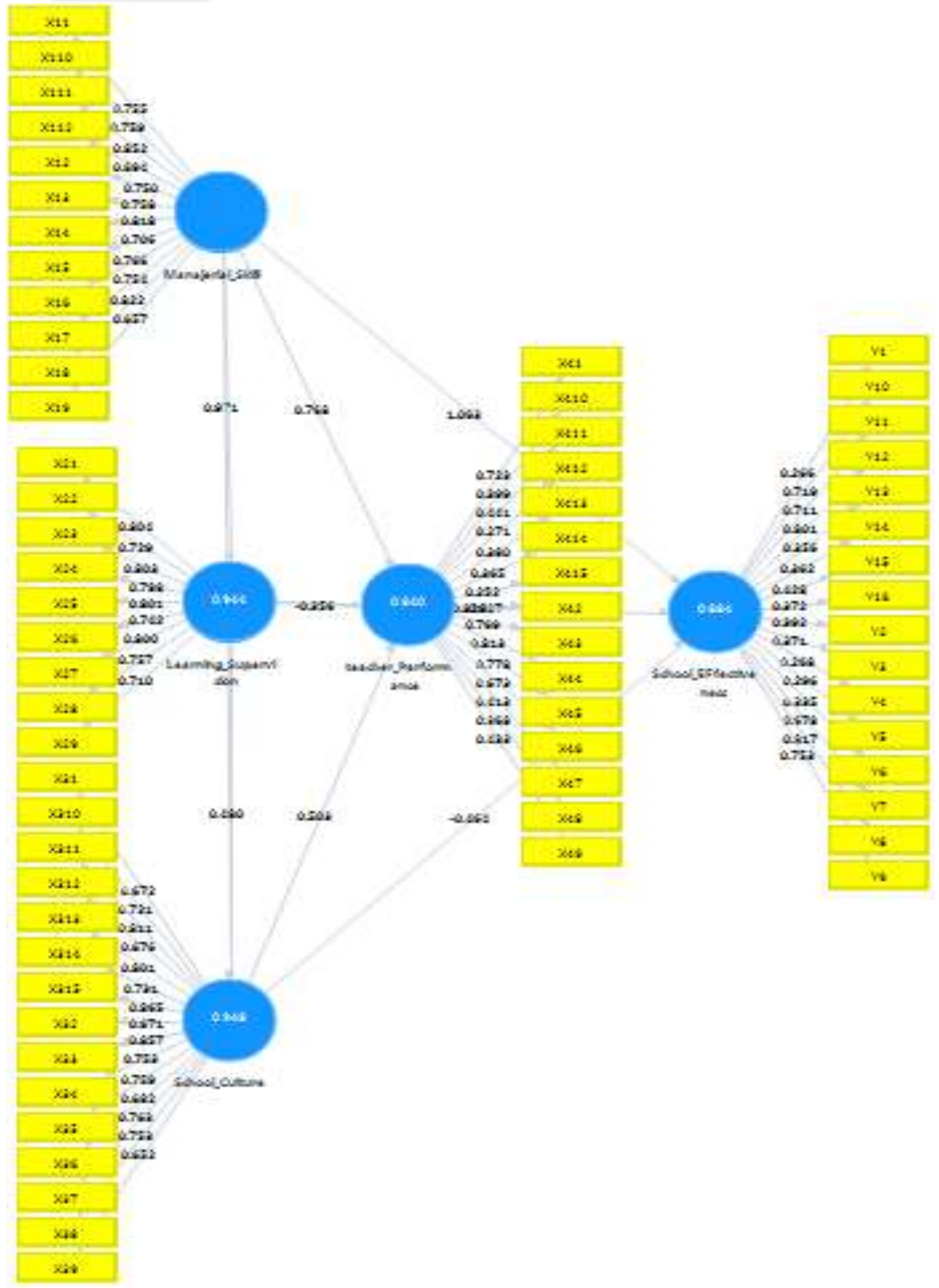

Figure 2. Measurement Model Assessment of the Effects of Principal's Managerial Skills, Learning Supervision, School Culture, and Teacher Performance on the Effectiveness of Madrasah Aliah Negeri 


\section{Convergent Validity}

Convergent validity in this study was intended to measure the research model based on the correlation between item scores from research results using PLS Software. Correlation results can be said to be high if they have a correlation value of more than 0.60 to the construct measured. In this research, a loading factor limit of 0.60 will be used (Abdillah \& Hartono, 2015; Ahmad \& Afthanorhan, 2014). The results of the analysis using the SEM PLS model show that the value of loading factors on the indicators for each variable in this research model can be explained in Table 2-6 as follows:

Table 2

Outer Loadings of Principal Managerial Skills

\begin{tabular}{cccc}
\hline Indicator & Research Model & Indicator & Research Model \\
\hline X11 & 0,755 & X17 & 0,818 \\
X12 & 0,759 & X18 & 0,706 \\
X13 & 0,582 & X19 & 0,766 \\
X14 & 0,694 & X10 & 0,754 \\
X15 & 0,750 & X11 & 0,822 \\
X16 & 0,758 & X12 & 0,657 \\
\hline
\end{tabular}

Table 3

Outer Loadings of Learning Supervision

\begin{tabular}{cccc}
\hline Indicator & Research Model & Indicator & Research Model \\
\hline X21 & 0,804 & X26 & 0,742 \\
X22 & 0,729 & X27 & 0,800 \\
X23 & 0,803 & X28 & 0,757 \\
X24 & 0,788 & X29 & 0,710 \\
X25 & 0,801 & & \\
\hline
\end{tabular}

Table 4

Outer Loadings of School Culture

\begin{tabular}{cccc}
\hline Indicator & Research Model & Indicator & Research Model \\
\hline X31 & 0,672 & X39 & 0,857 \\
X32 & 0,721 & X310 & 0,753 \\
X33 & 0,811 & X311 & 0,759 \\
X34 & 0,676 & X312 & 0,682 \\
X35 & 0,801 & X313 & 0,763 \\
X36 & 0,731 & X314 & 0,753 \\
X37 & 0,865 & X315 & 0,752 \\
X38 & 0,671 & & \\
\hline
\end{tabular}

Table 5

Outer Loadings of Teacher Performance

\begin{tabular}{cccc}
\hline Indicator & Research Model & Indicator & Research Model \\
\hline X41 & 0,723 & X49 & 0,769 \\
X42 & 0,799 & X410 & 0,813 \\
X43 & 0,741 & X411 & 0,778 \\
X44 & 0,771 & X412 & 0,637 \\
X45 & 0,780 & X413 & 0,813 \\
\hline
\end{tabular}




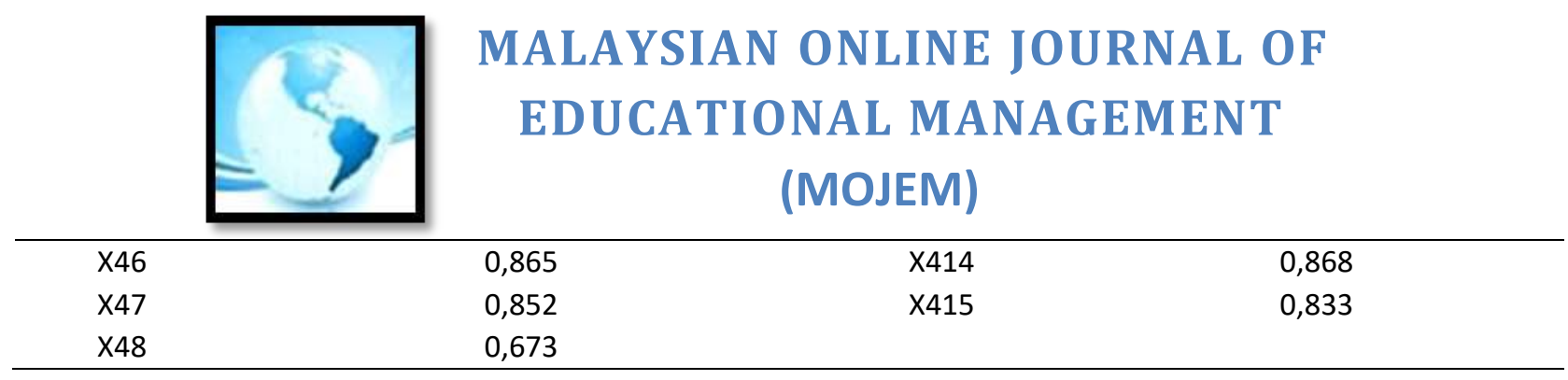

Table 6

Outer Loadings of School Effectiveness

\begin{tabular}{cccc}
\hline Indicator & Research Model & Indicator & Research Model \\
\hline Y1 & 0,766 & Y9 & 0,792 \\
Y2 & 0,719 & Y10 & 0,771 \\
X43 & 0,711 & Y11 & 0,868 \\
Y4 & 0,801 & Y12 & 0,796 \\
Y5 & 0,786 & Y13 & 0,835 \\
Y6 & 0,762 & Y14 & 0,778 \\
Y7 & 0,828 & Y15 & 0,813 \\
Y8 & 0,772 & Y16 & 0,772 \\
\hline
\end{tabular}

The results of the analysis above show that the value of the outer model or the relationship between the construct and the managerial skill variables of the principal, supervision of learning, school culture, teacher performance, and school effectiveness is stated to have fulfilled convergent validity based on the estimated results of outer loading test calculations using SmartPLS. The results of data analysis about outer loadings that have been described in Tables 2 through 6 can be concluded that all the research instrument items are in the valid category, this is because the factor loading values are all more than 0.6.

\section{Discriminant Validity Analysis}

The discriminant validity test can be implemented well if it is certain that all indicators of the latent variables contained in this study are constructs of the latent variables to be examined. The discriminant validity test is carried out to ascertain and ensure that the scale used in this study does not have two constructs that measure the same thing, so the correlation between constructs must be less than 0.90 . It is intended that the correlation between constructs should not exceed 0.90, there will be multicollinearity between constructs (Abdillah \& Hartono, 2015). The results of the discriminant validity test in this study are explained in table 7 :

Table 7

Discriminant Validity Analysis of Managerial Skills, Learning Supervision, School Culture, Teacher Performance, and School Effectiveness.

\begin{tabular}{cccccc}
\hline Indicator & Managerial Skills & $\begin{array}{c}\text { Learning } \\
\text { Supervision }\end{array}$ & $\begin{array}{c}\text { School } \\
\text { Culture }\end{array}$ & $\begin{array}{c}\text { Teacher } \\
\text { Performance }\end{array}$ & $\begin{array}{c}\text { School } \\
\text { Effectiveness }\end{array}$ \\
\hline X11 & 0.740 & 0.755 & 0.756 & 0.712 & 0.678 \\
X12 & 0.708 & 0.750 & 0.565 & 0.665 & 0.817 \\
X13 & 0.694 & 0.758 & 0.745 & 0.682 & 0.753 \\
X14 & 0.787 & 0.818 & 0.822 & 0.714 & 0.719 \\
X15 & 0.719 & 0.706 & 0.662 & 0.683 & 0.711 \\
X11 & 0.800 & 0.766 & 0.726 & 0.651 & 0.801 \\
X17 & 0.790 & 0.754 & 0.780 & 0.707 & 0.646 \\
X18 & 0.852 & 0.822 & 0.869 & 0.731 & 0.725 \\
X19 & 0.656 & 0.657 & 0.594 & 0.623 & 0.575 \\
X110 & 0.708 & 0.759 & 0.722 & 0.730 & 0.707 \\
X111 & 0.770 & 0.852 & 0.822 & 0.785 & 0.752 \\
X112 & 0.593 & 0.694 & 0.610 & 0.583 & 0.609 \\
\hline
\end{tabular}




\begin{tabular}{|c|c|c|c|c|c|}
\hline$X 21$ & 0.804 & 0.806 & 0.832 & 0.759 & 0.714 \\
\hline X22 & 0.729 & 0.702 & 0.636 & 0.610 & 0.744 \\
\hline$\times 23$ & 0.803 & 0.771 & 0.808 & 0.641 & 0.739 \\
\hline X24 & 0.788 & 0.776 & 0.784 & 0.689 & 0.657 \\
\hline$X 25$ & 0.801 & 0.778 & 0.760 & 0.714 & 0.774 \\
\hline X26 & 0.742 & 0.730 & 0.646 & 0.645 & 0.775 \\
\hline$\times 27$ & 0.800 & 0.756 & 0.793 & 0.733 & 0.645 \\
\hline$X 28$ & 0.757 & 0.728 & 0.760 & 0.693 & 0.672 \\
\hline X29 & 0.710 & 0.686 & 0.666 & 0.581 & 0.617 \\
\hline X31 & 0.671 & 0.661 & 0.672 & 0.594 & 0.604 \\
\hline X32 & 0.689 & 0.662 & 0.671 & 0.606 & 0.732 \\
\hline X33 & 0.805 & 0.809 & 0.857 & 0.729 & 0.744 \\
\hline X34 & 0.709 & 0.668 & 0.753 & 0.655 & 0.549 \\
\hline X35 & 0.654 & 0.668 & 0.759 & 0.607 & 0.585 \\
\hline X36 & 0.617 & 0.662 & 0.682 & 0.602 & 0.566 \\
\hline X37 & 0.725 & 0.695 & 0.763 & 0.633 & 0.563 \\
\hline X38 & 0.732 & 0.749 & 0.753 & 0.740 & 0.668 \\
\hline X39 & 0.704 & 0.747 & 0.652 & 0.681 & 0.813 \\
\hline X310 & 0.628 & 0.868 & 0.721 & 0.702 & 0.554 \\
\hline X311 & 0.774 & 0.803 & 0.811 & 0.688 & 0.696 \\
\hline X312 & 0.735 & 0.718 & 0.676 & 0.689 & 0.720 \\
\hline X313 & 0.757 & 0.716 & 0.801 & 0.658 & 0.626 \\
\hline X314 & 0.702 & 0.681 & 0.731 & 0.805 & 0.793 \\
\hline X315 & 0.863 & 0.845 & 0.671 & 0.606 & 0.732 \\
\hline X41 & 0.747 & 0.748 & 0.692 & 0.723 & 0.741 \\
\hline$X 42$ & 0.622 & 0.643 & 0.682 & 0.637 & 0.595 \\
\hline X43 & 0.680 & 0.738 & 0.768 & 0.769 & 0.638 \\
\hline X44 & 0.762 & 0.827 & 0.802 & 0.813 & 0.786 \\
\hline$X 45$ & 0.663 & 0.711 & 0.693 & 0.778 & 0.663 \\
\hline X46 & 0.674 & 0.647 & 0.684 & 0.673 & 0525 \\
\hline$X 47$ & 0.223 & 0.214 & 0.196 & 0.413 & 0.371 \\
\hline X48 & 0.133 & 0.142 & 0.133 & 0.368 & 0.183 \\
\hline X49 & 0.210 & 0.206 & 0.201 & 0.433 & 0.351 \\
\hline X410 & 0.206 & 0.204 & 0.192 & 0.399 & 0.344 \\
\hline X411 & 0.124 & 0.094 & 0.115 & 0.271 & 0.178 \\
\hline X412 & 0.124 & 0.094 & 0.115 & 0.217 & 0.178 \\
\hline X413 & 0.231 & 0.209 & 0.206 & 0.380 & 0.282 \\
\hline X414 & 0.209 & 0.223 & 0.173 & 0.365 & 0.371 \\
\hline X415 & 0.163 & 0.167 & 0.140 & 0.252 & 0.383 \\
\hline $\mathrm{Y} 1$ & 0.082 & 0.102 & 0.077 & 0.172 & 0.266 \\
\hline Y2 & 0.172 & 0.185 & 0.156 & 0.274 & 0.392 \\
\hline Y3 & 0.209 & 0.223 & 0.173 & 0.365 & 0.371 \\
\hline Y4 & 0.171 & 0.163 & 0.111 & 0.264 & 0.268 \\
\hline Y5 & 0.111 & 0.080 & 0.018 & 0.100 & 0.296 \\
\hline Y6 & 0.147 & 0.153 & 0.134 & 0.310 & 0.335 \\
\hline Y7 & 0.740 & 0.755 & 0.756 & 0.712 & 0.678 \\
\hline Y8 & 0.708 & 0.750 & 0.656 & 0.665 & 0.817 \\
\hline Y9 & 0.694 & 0.758 & 0.745 & 0.682 & 0.753 \\
\hline Y10 & 0.787 & 0.818 & 0822 & 0.714 & 0.719 \\
\hline Y11 & 0.719 & 0.706 & 0.662 & 0.683 & 0.711 \\
\hline
\end{tabular}




\begin{tabular}{|c|c|c|c|c|c|}
\hline \multirow[b]{2}{*}{ Y12 } & \multirow[b]{2}{*}{0.800} & \multicolumn{4}{|c|}{$\begin{array}{l}\text { MALAYSIAN ONLINE JOURNAL OF } \\
\text { EDUCATIONAL MANAGEMENT } \\
\text { (MOJEM) }\end{array}$} \\
\hline & & 0.766 & 0.726 & 0.651 & 0.801 \\
\hline Y13 & 0.140 & 0.139 & 0.091 & 0.215 & 0.356 \\
\hline Y14 & 0.144 & 0.145 & 0.096 & 0.236 & 0.362 \\
\hline Y15 & 0.181 & 0.191 & 0.148 & 0.332 & 0.428 \\
\hline Y16 & 0.163 & 0.158 & 0.155 & 0.311 & 0.372 \\
\hline
\end{tabular}

By the results of the analysis contained in the table above shows that there is no multicollinearity between variables because each construct measures different things. This is evident from the correlation value between constructs that are less than 0.90 .

\section{Reliability and AVE Analysis}

Research instruments must have the required level of reliability. The research model was carried out with a reliability test based on the results obtained from the reliability value of a construct and the AVE value of each research construct. If a construct has high reliability with a value of 0.70 and the AVE value is above 0.50 (Ghozali, 2011). Table 8 shows the results of the Composite Reliability and AVE analysis on all research variables.

Table 8

Outer Model, AVE, Composite Reliability Analysis of Managerial Skills, Learning Supervision, School Culture, Teacher Performance, and School Effectiveness

\begin{tabular}{lccc}
\hline \multicolumn{1}{c}{ Variable } & Cronbach's Alpha & Composite Reliability & AVE \\
\hline Learning Supervision & 0,914 & 0.929 & 0.595 \\
Managerial Skills & 0,933 & 0.942 & 0.577 \\
School Culture & 0,943 & 0.950 & 0.559 \\
Teacher Performance & 0,858 & 0.846 & 0.736 \\
School Effectiveness & 0,858 & 0.841 & 0.900 \\
\hline
\end{tabular}

The results of the analysis described in Table 8 can be concluded that the managerial skill variables, learning supervision, school culture, teacher performance, and school effectiveness have fulfilled the reliability requirements as indicated by the results of the composite reliability analysis scores above 0.70 and AVE in above 0.50 . The results of this analysis are by the criteria in composite reliability and AVE analysis.

\section{Data Analysis}

The main objective of this research was to describe the contribution of the principal's managerial ability, supervision of learning, school culture, and teacher performance to the effectiveness of schools in MAN Tulungagung. This study uses the Partial Least Square (PLS) approach in analysing research data based on SmartPLS software. Data analysis using Partial Least Square has similarities with SEM or Structural Equational Model (Sarstedt \& Cheah, 2019). The nature of PLS is an alternative approach in the analysis of research data developed based on the SEM approach, PLS was developed into a variant-based data analysis approach (Ghozali, 2011). Data analysis using the SEM approach based on covariance can be used to test quality or theory, whereas data analysis using PLS is more predictive of models (Sarstedt \& Cheah, 2019). PLS is a powerful data analysis method (Ghozali, 2011). Data analysis using PLS is not based on many assumptions in a study, as data must be normally distributed. Research that aims to test the theory, data analysis can use PLS, as well as PLS can be used to explain the influence between latent variables in a research model that has been designed by researchers (Silaparasetti, Rao, \& Khan, 2017). PLS can also be used to analyse constructs that are formed based on formative and reflexive indicators (Wong, 2019). The SEM cannot be used to analyse constructs that are formed with formative and reflexive indicators based on covariance because it will become an unidentified model. The condition of the research model can be analysed using the PLS technique. 


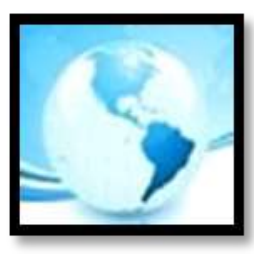

\section{MALAYSIAN ONLINE JOURNAL OF EDUCATIONAL MANAGEMENT (MOJEM)}

Analysis of research data with PLS can be carried out by assessing inner models or structural models and outer models or measurement models (Ghozali, 2011; Silaparasetti et al., 2017; Wong, 2019). Outer models can be assessed using Discriminant Validity, Convergent Validity, and Composite Reliability (Ghozali, 2011. Convergent Validity is a measurement model that assesses the effect or correlation between component scores or item scores with construct scores calculated based on reflective indicators using Partial Least Square. Measurement scale with loading values 0.5 to 0.6 can be used in research with Partial Least Square (Ghozali, 2011; Silaparasetti et al., 2017). The cross-loading value can be used as a reflexive measurement model of manifest variables or each indicator of latent variables to determine Discriminant Validity in a research model with PLS analysis. This Discriminant Validity will show a correlation between latent variables and manifest variables showing greater value than correlations with other latent variables, then the latent variable can predict its indicators or manifest variables better than other latent variables (Abdillah \& Hartono, 2015; Ferdinand, 2014). This can also be seen from the results of AVE analysis; discriminant validity can be said to be achieved if the Average Variance Extracted value is greater than 0.5. (Ghozali, 2011; Voorhees, Brady, Calantone, \& Ramirez, 2016).

Data analysis to test the structural model or inner model in the PLS approach can be carried out by knowing the relationship between constructs, R-square, and significant values of the research model being tested (Dong \& Qin, 2018). The inner model for the dependent construct variable can be assessed using R-square, for predictive relevance it can be assessed using the Stone-Geisser Q-square test and can be tested for the significance of the structural path parameter coefficient, as well as the t-test (Dong \& Qin, 2018; Richter, Cepeda-Carrión, Roldán Salgueiro, \& Ringle, 2016). The Partial Least Square model can be assessed based on R-square on each of the dependent latent variables in the study. R-square value from the results of data analysis can be used to determine the influence or relationship between the independent latent variable to the dependent latent variable by knowing the relationship of substantive influence in a research model with PLS (Ghozali, 2011; Dong \& Qin, 2018)

\section{RESULTS}

Research data mining was carried out after testing the validity and reliability of the instrument. The instrument was given to Madrasah Aliah Negeri teachers as respondents in this study. A total of 213 teachers were used as respondents to provide an assessment based on research instruments that had been tested for validity and reliability. The data collected in the implementation of this study were 200 instruments and 15 instruments could not be analysed, because they were damaged and not entirely available in each question item. Therefore, there are only 185 instruments that can be analysed. This number of 185 has met the research target as explained previously. For this reason, the data were analysed based on 185 instruments that had been filled out by respondents using Smart-PLS.

\section{Model Feasibility Test Results}

Testing the feasibility of the model is very important to do in research so that it can be known and can be ascertained that the structural model or inner model in a study is feasible to proceed. Testing the feasibility of the structural model or the inner model is analysed using R-square which is found in the significance of the structural path parameter coefficients and the t-test. Assessing the research model using Partial Least Square can be started by looking at the analysis results contained in the R-square of each dependent latent variable in this study. Table 9 below explains the results of the analysis based on R-Square contained in each research variable. 


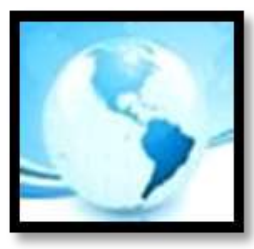

MALAYSIAN ONLINE JOURNAL OF

EDUCATIONAL MANAGEMENT

(MOJEM)

Table 9

R-Square Values of Managerial Skills, Learning Supervision, School Culture, Teacher Performance, and School Effectiveness

\begin{tabular}{|c|c|}
\hline Variable & R-Square \\
\hline Managerial Skills of Principal & 0.9351 \\
\hline Learning Supervision & 0,944 \\
\hline School Culture & 0.948 \\
\hline Teacher Performance & 0.840 \\
\hline School Effectiveness & 0.884 \\
\hline
\end{tabular}

Based on the analysis results in the structural model testing shows that the R-square value of the managerial skills variable obtained a value of 0.9351 , learning supervision obtained a value of 0.944 , the school culture variable obtained a value of 0.948 , the teacher performance variable obtained at 0.840 , while the school effectiveness variable obtained value of 0.884 .

\section{Hypothesis Test Results}

Hypothesis testing in this research model were carried out using the SmartPLS data analysis program. Hypothesis testing in every relationship contained in this research model is simulated using the bootstrap method in the study sample. Hypothesis testing using bootstrap is intended to minimize the abnormality of research data. Figure 3 is a hypothetical model or structural model developed in this study. 


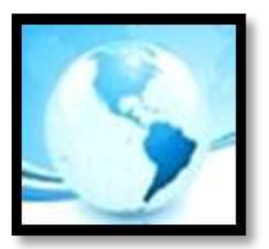

MALAYSIAN ONLINE JOURNAL OF

EDUCATIONAL MANAGEMENT

(MOJEM)

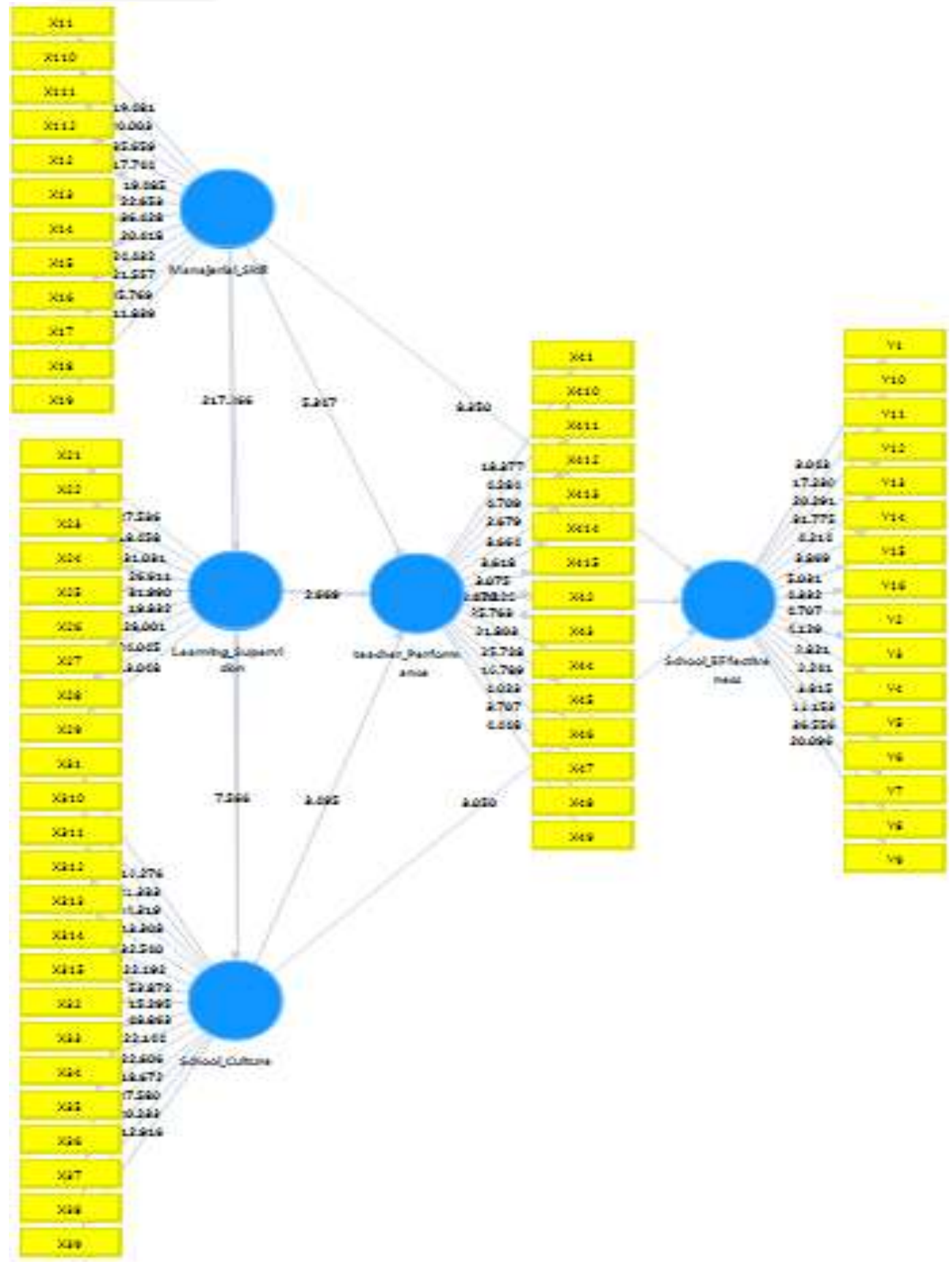

Figure 3. Results of Bootstrapping of Managerial Skills, Learning Supervision, School Culture, Teacher Performance, and School Effectiveness

The hypothesis test was carried out to explain the level of significance of the relationship or influence between variables in the research model, this level of significance is measured using parameter values generated in the path coefficient (Abdillah \& Hartono, 2015). This hypothesis test is based on estimated path coefficients and t-statistical 


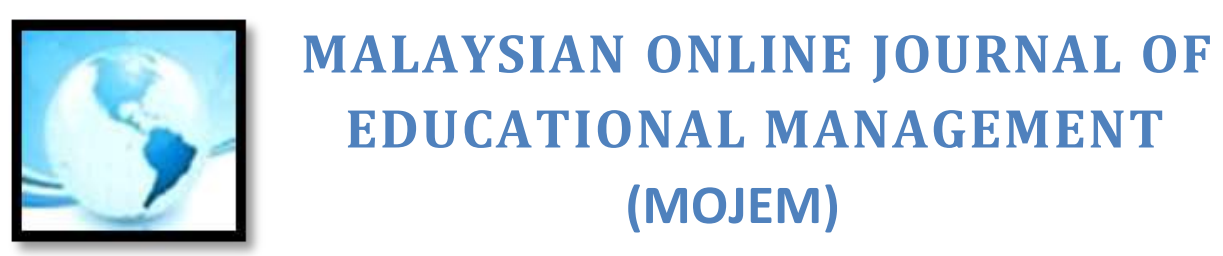

values at the significance level $\alpha=5 \%$. Hypothesis testing can be accepted if the results of the t-statistic value are higher than the t-table value of 1.88 . The results of hypothesis testing in this study can be seen in Table 10 below:

Table 10

Path Coefficient Value of Managerial Skills, Learning Supervision, School Culture, Teacher Performance, and School Effectiveness

\begin{tabular}{|c|c|c|c|c|c|c|c|}
\hline No. & Correlation & $\begin{array}{l}\text { Original } \\
\text { Sample }\end{array}$ & $\begin{array}{l}\text { jample } \\
\text { Vean (M) }\end{array}$ & $\begin{array}{l}\text { Standard } \\
\text { Deviation }\end{array}$ & T-Statistic & P-Values & Decision \\
\hline 1 & $\begin{array}{l}\text { Managerial Skill -> } \\
\text { Learning Supervision }\end{array}$ & 0.848 & 0.849 & 0.021 & 41.237 & 0.000 & Accepted \\
\hline 2 & $\begin{array}{l}\text { Managerial Skill -> } \\
\text { School Culture }\end{array}$ & 0.180 & 0.181 & 0.081 & 2.236 & 0.026 & Accepted \\
\hline 3 & $\begin{array}{l}\text { Learning Supervision - } \\
\text { > School Cultural }\end{array}$ & 0.707 & 0.709 & 0.082 & 8.590 & 0.000 & Accepted \\
\hline 4 & $\begin{array}{l}\text { Managerial Skill -> } \\
\text { Teacher Performance }\end{array}$ & 0.504 & 0.505 & 0.070 & 7.177 & 0.000 & Accepted \\
\hline 5 & $\begin{array}{l}\text { Learning Supervision - } \\
>\quad \text { Teacher } \\
\text { Performance }\end{array}$ & 0.204 & 0.204 & 0.079 & 2.568 & 0.011 & Accepted \\
\hline 6 & $\begin{array}{l}\text { School Culture -> } \\
\text { Teacher Performance }\end{array}$ & 0.276 & 0.275 & 0.071 & 3.870 & 0.000 & Accepted \\
\hline 7 & $\begin{array}{l}\text { Managerial Skill -> } \\
\text { School Effectiveness }\end{array}$ & 0.307 & 0.302 & 0.035 & 8.888 & 0.000 & Accepted \\
\hline 8 & $\begin{array}{l}\text { Learning Supervision - } \\
>\text { School Effectiveness }\end{array}$ & 0.571 & 0.566 & 0.036 & 16.093 & 0.000 & Accepted \\
\hline 9 & $\begin{array}{l}\text { School Culture -> } \\
\text { School Effectiveness }\end{array}$ & 0.430 & 0.436 & 0.036 & 12.075 & 0.000 & Accepted \\
\hline 10 & $\begin{array}{l}\text { Teacher Performance - } \\
>\text { School Effectiveness }\end{array}$ & -0.287 & -0.283 & 0.041 & 6.922 & 0.000 & Accepted \\
\hline
\end{tabular}

Hypothesis test results about the effect of principals' managerial skills on the implementation of supervised learning in schools produced an at-value of 41,237 with a P-value of 0,000 <from 0.05 (sig level). Based on the results of the analysis, it has been proven that the hypothesis test in this research model is accepted and the conclusion is that there is a strong influence between the managerial skills of the principal and the implementation of instructional supervision in school. The results of hypothesis testing about the managerial ability of principals on school culture generated a t-statistic value of 2,236 with a P-value of 0.026 <from 0.05 (sig level). These results prove that the hypothesis proposed in this study can be well accepted, that the managerial skill of the principal influences the formation of school culture.

Data analysis of instructional supervision variables on school culture can produce a statistical t value of 8,590 with a P-value of $0,000<$ from 0.05 (sig level). The results of the analysis can be explained that the supervision of learning has a strong influence on the formation of school culture. Hypothesis testing about the principal's managerial skills on teacher performance produced a t-statistic value of 7,177 with a P-value of $0,000<$ from 0.05 (sig level). The results of the analysis show that the principal's managerial skills have a strong influence on teacher performance.

Hypothesis testing of research on the effect of learning supervision on teacher performance produced at a value of 2.568 with a P-value of 0.011 <of 0.05 (sig level). This shows that the hypothesis proposed in this study is 


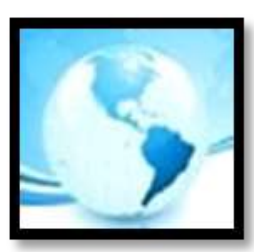

acceptable because learning supervision influences teacher performance. The results of this study provide clues that implementing good learning supervision can improve teacher performance in schools.

The results of an analysis of the influence of school culture on teacher performance obtained a value of 3,870 with a P-value of $0,000<$ from 0.05 (sig level). This can be explained that there is an influence between school culture on teacher performance. The results of the analysis of the effect of managerial skills on school effectiveness produced a statistical value of 8,888 with a P-value of $0,000<$ from 0.05 (sig level). This proves that the research hypothesis about the effect of managerial skills has a significant effect on school effectiveness in the Madrasah Aliah Negeri Tulungagung, Indonesia.

The relationship between learning supervision and school effectiveness obtained a value of 16,093 with a $\mathrm{P}$-value of $0,000<$ from 0.05 (sig level). These results indicate that there is an influence between learning supervision on school effectiveness. This shows that the better the implementation of learning supervision will result in more effective schools in MAN Tulungagung Indonesia. Hypothesis testing about the relationship between school culture and school effectiveness resulted in a value of 12,075 with a P-value of $0,000<$ from 0.05 (sig level). Based on these results it shows that there is a relationship between school culture and school effectiveness in the Madrasah Aliah Negeri Tulungagung. The hypothesis test about teacher performance against school effectiveness can produce a statistical t value of 6.922 with a P-value of $0.000<$ from 0.05 (sig level). The results of the analysis show that there is an influence on teacher performance on school effectiveness.

\section{Mediation Testing Results}

Analysis of the influence between variables in this study was carried out to analyse the strength of the influence that exists in each research variable either directly, indirect influence, or the total effect. The direct effect in this study is closely related to the coefficients of all the coefficient lines shown by each arrow at the end. While the indirect effect is related to the influence that appears through an intermediate variable. VAF (Variance Accounted For) is a measure of how large a variable that functions as a mediator can absorb the direct influence that was previously significant from the model without mediation. VAF above $80 \%$, then aiming at the role of full mediation. If the VAF has a value between $20 \%-80 \%$ it can be a partial mediator. However, if the VAF is less than $20 \%$ it shows almost no mediating effect (Ferdinand, 2014; Groenen \& Meulman, 2004).

Table 11

Indirect Effects of Managerial Skills, Learning Supervision, School Culture, Teacher Performance, and School Effectiveness

\begin{tabular}{|c|c|c|c|c|c|c|c|}
\hline No. & Correlation & & $\begin{array}{l}\text { Original } \\
\text { Sample }\end{array}$ & $\begin{array}{l}\text { Sample } \\
\text { Mean (M) }\end{array}$ & $\begin{array}{l}\text { Standard } \\
\text { Deviation }\end{array}$ & T-Statistic & P Values \\
\hline 1 & $\begin{array}{l}\text { Learning Supervision } \\
\text { School Effectiveness }\end{array}$ & $\rightarrow$ & 0.189 & 0.197 & 0.053 & 3.600 & 0.000 \\
\hline 2 & $\begin{array}{l}\text { Learning Supervision } \\
\text { Teacher Performance }\end{array}$ & $->$ & 0.195 & 0.195 & 0.059 & 3.330 & 0.001 \\
\hline 3 & $\begin{array}{l}\text { Managerial Skill -> } \\
\text { School Cultural }\end{array}$ & & 0.599 & 0.602 & 0.073 & 8.228 & 0.000 \\
\hline 4 & $\begin{array}{l}\text { Managerial Skill -> } \\
\text { School Effectiveness }\end{array}$ & & 0.564 & 0.569 & 0.037 & 15.237 & 0.000 \\
\hline 5 & $\begin{array}{l}\text { Managerial Skill -> } \\
\text { Teacher Performance }\end{array}$ & & 0.388 & 0.388 & 0.059 & 6.601 & 0.000 \\
\hline 6 & $\begin{array}{l}\text { School Culture -> } \\
\text { School Effectiveness }\end{array}$ & & -0.079 & -0.078 & 0.023 & 3.376 & 0.001 \\
\hline
\end{tabular}




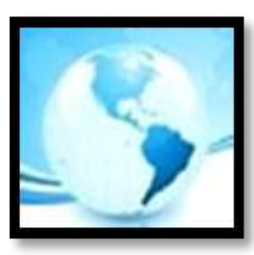

\section{MALAYSIAN ONLINE JOURNAL OF EDUCATIONAL MANAGEMENT (MOJEM)}

From Table 11 above, the results showcases the indirect effect between learning supervision on school effectiveness P-values $0,000<0.05$ this means significant. The results of the indirect effect between learning supervision on teacher performance p-values $0.001<0.05$ means significant. The result of the indirect effect of managerial skill on school cultural p-values $0,000<0.05$ is significant. The result of the indirect effect of managerial skill on school effectiveness $0,000<0.05$ is significant. The result of the indirect effect of managerial skill on teacher performance $0,000<0.05$ is significant. The indirect effect of school culture on school effectiveness $0,000<0.05$ is significant.

\section{DISCUSSIONS}

Principals as leaders and managers have the duty and responsibility to be able to manage the school to be effective and quality. Effective schools are the hopes and needs of the community both nationally and internationally. The effectiveness of schools is largely determined by the principal in making strategic policies and programs implemented in schools. The results showed that the better managerial skills possessed by school principals, the better the implementation of learning supervision, the formation of school culture, teacher performance, and the ability to create effective schools. The findings of this study can strengthen the results of previous studies which explain that the dimensions of knowledge and technical skills have an influence on teacher attitudes and the implementation of supervision by school principals (Khun-Inkeeree, Dali, Daud, Fauzee, \& Khalid, 2019). Managerial skills can improve performance in organizations (Hysong, 2008). Leadership can also improve teacher performance (Sudarjat et al., 2015). Leadership has a role in creating organizational reality (Reynolds, 1993). In connection with this Mondy (1990) explains that the managerial skills of leaders are sure to influence organizational behaviours. Bass and Stogdill (1981) alongside Bates, Sergiovanni, and Corbally, (1984) also explained that organizational effectiveness is a consequence of managerial skills possessed by a leader. The explanation shows that the principal is the key to success in improving the quality and effectiveness of the school. Effective schools need professional and committed principals to improve the quality of education.

The principal's commitment to improving the quality of education and creating effective schools is a very important issue to be discussed. Commitments held by the principal must be supported by competence in carrying out leadership tasks because the principal is the key to success in school. This condition is supported by the results of research that explain that the principal's managerial competence can increase teacher job satisfaction and teacher performance (Ibrahim, 2018; Sihombing et al., 2019). Principal's managerial competence can increase teacher job satisfaction and teacher performance (Ibrahim, 2018; Sihombing et al., 2019). There is a positive impact between managerial competence and the implementation of supervision on employee performance (Vijayabanu \& Therasa, 2016). Good school leadership has a positive influence on teachers in improving performance because school principals can empower teachers to be more committed to improving learning in schools (Amzat, 2017). This discussion shows that the findings of a significant direct relationship between principals' managerial skills and supervision of learning reinforce the results of previous similar studies. The results of this study imply that the better managerial skills possessed by principals, the better they will be in implementing the supervision of learning. Therefore, training of principals' managerial skills must be carried out continuously so that the principal can carry out their duties and responsibilities properly and successfully.

Academic supervision carried out by the school principal can improve teacher competence (Fahmi, Murniati, Nurliza, \& Usman, 2019). Implementation of the Supervision of Work Morale can improve the culture and performance of teachers, improving the morale of work and quality culture can improve Teacher Performance (Kecapi et al., 2020). There is an influence between academic supervision on school culture and the quality of teaching of teachers (Mujiati et al., 2019). The results of the research by Renata, Wardiah, and Kristiawan (2018) show that there is an influence between the implementation of supervision on the effectiveness of the work of teachers in schools. There is a significant influence between the skills possessed by the principal on the attitudes and performance of teachers (Khun-Inkeeree et al., 2019). School culture has a very important role in increasing teacher motivation and performance (Gross, 2019). The results of this study reinforce that supervision of learning 


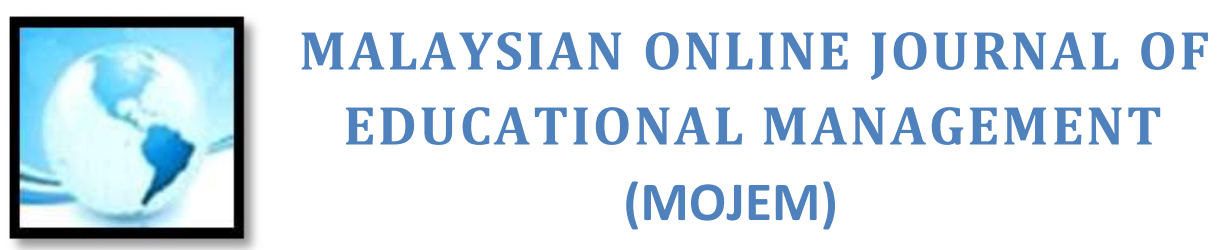

must be carried out well by the principal so that teachers become professional and able to improve performance effectively and be able to form a strong school culture. Teachers must be fostered continuously to become a professional teacher. Professional teachers can carry out their duties and responsibilities effectively in delivering students success in school. Student success is largely determined by the ability of teachers to carry out the learning process in the classroom.

There is a significant influence between school culture and school effectiveness or the better the school culture, the more effective the school (Ali et al., 2017). School culture has a positive influence on the effectiveness of student learning and teacher performance in schools (Dogan, 2017). Improved school quality can be realized with a positive school climate, this can be realized by creating conditions for students to learn well and teachers can work effectively, feel supported, safe, motivated, and satisfied with the work and learning outcomes they achieve (Dernowska, 2017). Instructional leadership and work involvement affect school culture, school culture can contribute to developing positive values in a participatory manner so that schools become effective (ZahedBabelan et al., 2019). School climate influences student achievement. Student motivation, achievement, and strategies used during learning are the main components in streamlining the learning process at school (Hollifield, 2019).

The performance of teachers and all personnel in the education institution becomes very important to be considered and continuously improved so that schools become effective and quality. There is a correlation between teacher performance with school culture (Hakim, Sa'ud, Komariah, \& Sunaengsih, 2018; Seashore Louis, \& Lee, 2016; Zahed-Babelan, Koulaei, Moeinikia, \& Sharif, 2019). There is an influence between social competence and pedagogical teachers on school culture (Nemet, 2017). Teacher capacities as education in implementing learning in schools will influence the formation of school culture (Sabancı, Şahin, Sönmez, \& Yılmaz, 2017; Seashore Louis, \& Lee, 2016). The results of this study indicate that the performance of teachers in schools needs to be improved on an ongoing basis to form an effective school culture. This school culture will be able to help in improving the quality of existing schools.

School culture has a very strong influence in creating effective schools (Ali et al., 2017; Dogan, 2017). School culture also influences professional development in schools (Rauf, Ali, Aluwi, \& Noor, 2018). The formation of positive and strong school culture can form effective schools (Lewis, Asberry, DeJarnett, \& King, 2016). This condition will be realized if there are leaders in the school who can mobilize all the school's human resources to be able to carry out their duties, roles, and responsibilities properly. good and bad conditions in schools are more determined by the leadership behaviours of the principal, including in shaping the culture of the school and creating an effective school. The principal's leadership will be able to form an effective school and school culture (Bipath \& Moyo, 2016). Principals' leadership and school culture have a strong influence on forming effective schools (Dahiru, Basri, Aji, \& Asimiran, 2018; Smart, 2016). School culture must be improved according to the core values developed in schools so that they can assist in improving the quality of education and forming effective schools.

An effective school is very important in improving the quality of education. The quality of education is the need of every person and customer of education at both the national and international levels. The effectiveness of education can be realized with the existence of leadership who can make strategic decisions and able to move the entire academic community to have a shared commitment to improving the quality of education in schools. Commitment can be a force to act in implementing performance and shaping effective school culture. The formation of productive performance and a strong and effective school culture can create effective and quality schools. Effective schools are in demand by many education customers both internal and external customers. To realize an effective school, there needs to be a professional and visionary headmaster's leadership that is equipped with high managerial skills in managing the school effectively and efficiently. 


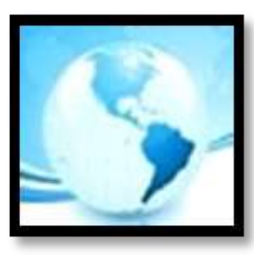

MALAYSIAN ONLINE JOURNAL OF

EDUCATIONAL MANAGEMENT

(MOJEM)

\section{IMPLICATIONS}

The effort to create an effective school is a problem faced by most educational institutions in Indonesia. The findings of this study carry practical implications that can be implemented by every school in forming an effective school. The implications are: (1) the principal must have managerial skills related to conceptual skills, technical skills, and human skills to be able to carry out their duties and responsibilities well (Katz, 2009). Principal's managerial skills can be improved on an ongoing basis because it has been proven to form effective schools. Conceptually the headmaster must master about education and how to manage the school effectively, technically the headmaster can carry out his role and function properly, while the human headmaster can collaborate with the entire academic community in creating an effective school, (2) Supervision of learning can implement continuously in increasing teacher professionalism to improve teacher performance (Kecapi et al., 2020), shape school culture (Mujiati et al., 2019), and create school effectiveness (Renata et al., 2018), (3) good teacher performance can be improved continuously to be able to form a strong school culture and effective school (Gross, 2019), (4) strong school culture makes members more satisfied, motivated and have a great commitment to the organization (Bates et al., 1984; Reynolds, 1993; Reynolds, 2018). A strong school culture will affect the behaviours of all school members to run the school's core values in achieving the vision and mission of the school so that an effective school is created. Effective schools are educational institutions that can achieve results by what is expected and aspire. The needs and expectations to be achieved can be used as a driving force for schools to achieve quality education.

\section{CONCLUSION}

This study has proven that school effectiveness is a condition that must be realized by every school to be able to meet the demands and needs of educational stakeholders. Effective schools are largely determined by the leadership and managerial skills possessed by the principal. The principal can guide teachers so that they can improve professional competence and teacher performance. Good and productive teacher performance can shape work culture in schools so that it can continuously improve the quality of education and create effective schools. Supervision of learning, teacher performance, and school culture are variables that must be considered in improving school effectiveness. School principals must be able to carry out continuous improvement and quality improvement to realize an effective school.

\section{REFERENCES}

Aaseb $\varnothing$, T. S., Midtsundstad, J. H., \& Willbergh, I. (2017). Teaching in the age of accountability: Restrained by school culture? Journal of Curriculum Studies, 49(3), 273-290.

Abdillah, W., \& Hartono, J. (2015). Partial Least Square (PLS): Alternatif Structural Equation Modeling (SEM) Dalam Pnelitian Bisnis [Partial Least Square (PLS): Alternative Structural Equation Modeling (SEM) in Business Research]. Yogyakarta: Penerbit Andi

Abdullah, M. (2019). School culture to serve performance of madrasah in Indonesia. QIJIS: Qudus International Journal of Islamic Studies, 7(1), 71-100.

Aguinis, H. (2009). An expanded view of performance management. In J.W. Smither \& M. London (eds.), Performance Management: Putting research into action (pp. 41-44). San Francisco, US: Jossey-Bass.

Ahmad, S., \& Afthanorhan, W. M. A. B. W. (2014). The importance-performance matrix analysis in partial least square structural equation modeling (PLS-SEM) with smart pls $2.0 \mathrm{M} 3$. International Journal of Mathematics Research, 3(1), 1-14.

Ali, N., Sharma, S., \& Zaman, A. (2017). School culture and school effectiveness: secondary schools in Pakistan. MOJEM: Malaysian Online Journal of Educational Management, 4(4), 50-65. 


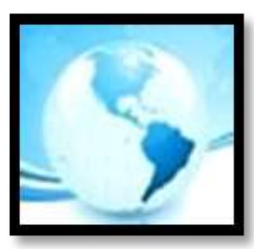

MALAYSIAN ONLINE JOURNAL OF

EDUCATIONAL MANAGEMENT

(MOJEM)

Ameen, A., Yousef Sandhu, K., \& Hussain Rana, A. (2019). Leadership and educational excellence through mediating role of total quality management implementation: An empirical evidence from higher education institutes. European Online Journal of Natural and Social Sciences: Proceedings, 8(4), 64-75.

Amzat, I. H. (2017). Principal instructional leadership practice and its effect on teachers' reflective practices: Indicators for best classroom practices. In Teacher Professional Knowledge and Development for Reflective and Inclusive Practices (pp. 70-88). Oxfordshire: Routledge.

Bass, B. M., \& Stogdill, R. (1981). Handbook of leadership. Theory, research, and managerial. USA: Free Press.

Bates, R. J. (1984). Toward a critical practice of educational administration. In T. J. Sergiovanni \& J. E. Corbally (Eds.), Leadership and organizational culture: New perspectives on administrative theory (pp. 260-274). Urbana, IL: University of Illinois Press.

Behrani, P. (2016). Implementation aspects of life skills education program on the central board of secondary education schools. International Education and Research Journal, 2(3), 68-71.

Bellei, C., Morawietz, L., Valenzuela, J. P., \& Vanni, X. (2019). Effective schools 10 years on factors and processes enabling the sustainability of school effectiveness. School Effectiveness and School Improvement, 31(2), 266-288. doi:10.1080/09243453.2019.1652191

Bipath, K., \& Moyo, E. (2016). Principals shaping school culture for school effectiveness in South Africa. Journal of Social Sciences, 48(3), 174-186.

Byrne, B. M. (2012). A primer of LISREL: Basic applications and programming for confirmatory factor analytic models. New York: Springer Science \& Business Media.

Cerit, Y., \& Yıldırım, B. (2017). The relationship between primary school principals' effective leadership behaviors and school effectiveness. Bartın Üniversitesi Eğitim Fakültesi Dergisi, 6(3), 902-914.

Codd, E.F. (1970). A relational model for large shared data banks, Comm. ACM (13)6, pp. 377-387.

Creemers, B. P., \& Kyriakides, L. (2006). Critical analysis of the current approaches to modeling educational effectiveness: The importance of establishing a dynamic model. School effectiveness and school improvement, 17(3), 347-366.

Dahiru, A. S., Basri, R., Aji, A. A., \& Asimiran, S. (2018). Modelling Social System for School Effectiveness. International Journal of Academic Research in Business Social Sciences, 8(12), 178-186.

Deal, T. E., \& Peterson, K. D. (2016). Shaping school culture. CA: John Wiley \& Sons.

Dernowska, U. (2017). Teacher and student perceptions of school climate. Some conclusions from school culture and climate research. Journal of Modern Science, 32(1), 63-82.

DeRoche, E. F. (1985). How school administrators solve problems. London: Prentice-Hall, Inc.

Dessler, G. (1997). Human resources management. New Jersey: Prentice-Hall.

Dong, Y., \& Qin, S. J. (2018). Regression on dynamic PLS structures for supervised learning of dynamic data. Journal of Process Control, 68, 64-72.

Dogan, M. (2017). School culture and effectiveness. Electronic Turkish Studies, 12(25), 253-264.

Fahmi, C. N., Murniati, A. R., Nurliza, E., \& Usman, N. (2019). The implementation of academic supervision in improving teacher competency at primary school. Jurnal Ilmiah Peuradeun, 7(1), 181-194.

Ferdinand, A. T. (2014). Structural Equation Model Dalam Penelitian Manajemen, Aplikasi Model-Model Rumit Dalam Penelitian Untuk Skripsi [Structural Equation Model in Management Research, Application of Complex Models in Research for Thesis]. (Doctoral dissertation, FEd. BU Diponegoro). Semarang, Indonesia: BP Undip-Undip Press.

Fieldman, D. C., \& Arnold, H. J. (1983). Managing individual and group behaviours in organization. Singapore: McGraw-Hill Book Company.

Gagne, R. M., \& Briggs, L. J. (1974). Principles of instructional design. New York: Holt, Rinehart \& Winston.

Ghozali, I. (2011). Structural Equation Modeling Metode Alternatif Dengan Partial Least Square (PLS) [Structural Equation Modeling Metode Alternatif with Partial Least Square (PLS)]. Indonesia: Badan Penerbit Universitas Diponegoro.

Glickman, C. D. (1981). Developmental supervision: Alternative practices for helping teachers improve instruction. Alexandria, VA: Association for Supervision \& Curriculum. 


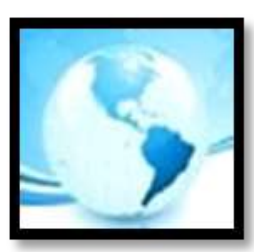

\section{MALAYSIAN ONLINE JOURNAL OF EDUCATIONAL MANAGEMENT (MOJEM)}

Goodman, J., \& Adler, S. (1985). Becoming an elementary social studies teacher: A study of perspectives. Theory \& Research in Social Education, 13(2), 1-20.

Granvik, S. M., Brolin, L. S., Almquist, Y. B., \& Modin, B. (2018). Effective schools, school segregation, and the link with school achievement. School effectiveness and school improvement, 29(3), 464-484.

Groenen, P. J., \& Meulman, J. J. (2004). A comparison of the ratio of variances in distance-based and classical multivariate analysis. Statistica Neerlandica, 58(4), 428-439.

Gross, B. (2019). The impact of school culture and leadership on job satisfaction and teacher autonomy. Ann Fradkin-Hayslip. The English Record, 69(2) 15-36.

Hakim, D. L., Sa'ud, U. S., Komariah, A., \& Sunaengsih, C. (2018, August). Teachers' teaching performance: Pedagogical competence, work motivation, school culture, and profession allowance. In Educational Administration Innovation for Sustainable Development: Proceedings of the International Conference on Research of Educational Administration and Management (ICREAM 2017), October 17, 2017, Bandung, Indonesia (p. 81). CRC Press.

Hargreaves, D. H. (1995). School culture, school effectiveness, and school improvement. School effectiveness and school improvement, 6(1), 23-46.

Hartnell, C. A., Ou, A. Y., \& Kinicki, A. (2011). Organizational culture and organizational effectiveness: a metaanalytic investigation of the competing values framework's theoretical suppositions. Journal of Applied Psychology, 96(4), 677-694.

Hersey, P., Blanchard, K. H., \& Johnson, D. E. (2007). Management of organizational behaviours. Upper Saddle River, NJ: Prentice-Hall.

Heyward, S. (2014). Reforming teaching practice in Indonesia: A case study of the implementation of active learning in North Maluku primary schools (Doctoral dissertation). University of Tasmania, Australia.

Hollifield, J. (2019). Teacher perceptions on the effects of school culture and climate on student achievement: $A$ qualitative multi-case study (Doctoral dissertation). Northcentral University, USA.

Hysong, S. J. (2008). The role of technical skill in perceptions of managerial performance. Journal of Management Development, 27(3), 275-290.

Ibrahim, F. W. (2018). Managerial and supervision competence at junior high school level. European Research Studies Journal, 21(3), 327-336.

Ikhwan, A. (2017). Development of quality management Islamic Education in Islamic boarding school (Case Study Madrasah Aliyah Ash Sholihin). Al-Hayat: Journal of Islamic Education, 1(1), 91-117.

Indonesia, P. R. (2003). Undang-Undang Republik Indonesia Nomor 20 Tahun 2003 tentang Sistem Pendidikan Nasional. [Law of the Republic of Indonesia Number 20, Year 2003 concerning the National Education System]. Jakarta: Pemerintah Republik Indonesia.

Iroegbu, E. E., \& Etudor-Eyo, E. (2016). Principals' instructional supervision and teachers' effectiveness. British Journal of Education, 4(7), 99-109.

Jacob, B. A., Rockoff, J. E., Taylor, E. S., Lindy, B., \& Rosen, R. (2018). Teacher applicant hiring and teacher performance: Evidence from DC public schools. Journal of Public Economics, 166, 81-97.

Jones, G. R., \& George, J. M. (2014). Essentials of contemporary management. NY: McGraw-Hill Education.

Kagema, J., \& Irungu, C. (2018). An analysis of teacher performance appraisals and their influence on teacher performance in secondary schools in Kenya. International Journal of Education, 11(1), 93-98.

Katz, R. L. (2009). Skills of an effective administrator. US: Harvard Business Review Press.

Kecapi, I. N., Maba, W., \& Paramartha, W. (2020). Principal leadership, work spirit, supervision, cultural quality with the performance of Hindu vocational schoolteachers. International journal of social sciences and humanities, 4(1), 13-22.

Khun-Inkeeree, H., Dali, P. D., Daud, Y., Fauzee, M. S. O., \& Khalid, R. (2019). Effects of teaching and learning supervision on teachers' attitudes to supervision at secondary school in Kubang Pasu District, Kedah. International Journal of Instruction, 12(1), 1335-1350.

Klein, H. J., \& Snell, S. A. (1994). The impact of the interview process and context on performance appraisal interview effectiveness. Journal of Managerial Issues, 160-175. 


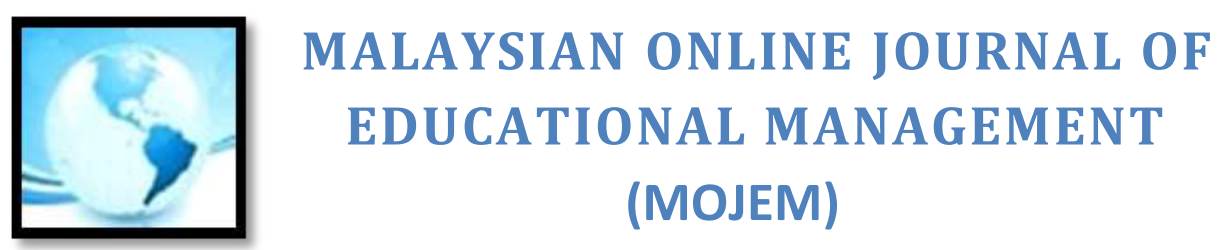

Kumara, S. K. (2018). Importance of teacher education for effective schools. Asian Journal of Development Matters, 12(1), 95-100.

Kyriakides, L., Creemers, B. P., \& Charalambous, E. (2019). Searching for differential teacher and school effectiveness in terms of student socioeconomic status and gender: Implications for promoting equity. School Effectiveness and School Improvement, 30(3), 286-308.

Langton, N., \& Robbins, S. P. (2007). Organizational behaviours: Concepts, controversies, applications. Canada: Pearson Prentice Hall.

Lee, M., \& Louis, K. S. (2019). Mapping a strong school culture and linking it to sustainable school improvement. Teaching and Teacher Education, 81, 84-96.

Lewis, J., Asberry, J., DeJarnett, G., \& King, G. (2016). The best practices for shaping school culture for instructional leaders. Alabama Journal of Educational Leadership, 3, 57-63.

Lovell, J. T., \& Wiles, K. (1983). Supervision for better schools. Englewood Cliffs, NJ: Prentice-Hall.

McConnell, C. R. (2016). Umiker's management skills for the new health care supervisor. USA: Jones \& Bartlett Learning.

Magut, T. J., Chumba, S., \& Kindiki, J. (2017). Headteachers' instructional supervision and its effect on academic performance in public primary schools in Ol'lessos Division, Nandi County, Kenya. JEP, 8(19), 215-224.

Majumdar, B. (2018). School principals as leaders: Major research trends and future directions. In Positive Schooling and Child Development (pp. 325-345). Singapore: Springer.

Mangkunegara, A. P., \& Prabu, A. (2004). Manajemen sumber daya manusia [Human Resource Management]. Bandung: PT. Remaja Rsodakarya.

Mantja, W. (2002). Manajemen pendidikan dan supervisi pengajaran [ Educational management and teaching supervision]. Malang: Wineka Media.

Marks, H. M., \& Louis, K. S. (1997). Does teacher empowerment affect the classroom? The implication of teacher empowerment for instructional practice and student academic performance. Educational Evaluation and Policy Analysis, 19(3), 245-275.

Maskur, M., Haryono, H., \& Hidayah, I. (2018). Contribution of supervision of school supervisor and school quality culture on primary school's managerial competence. Educational Management, 7(1), 25-32.

Mujhiyat, A., Abdullah, T., \& Akbar, M. (2018, November). The effect of leadership, organization culture, and work motivation on job performance of principal of state primary school in South Tangerang Banten. In First International Conference on Technology and Educational Science . doi: 10.4108/eai.21-11-2018.2282113

Mujiati, M., Suriansyah, A., \& Effendi, R. (2019). Effect of academic supervision and school culture on teacher's teaching quality in public Islamic Senior High School Banjarmasin. Journal of K6, Education and Management, 2(2), 126-132.

Mujtaba, B. G., \& Kaifi, B. A. (2011). Management skills of Afghan respondents: A comparison of technical, human, and conceptual differences based on gender. Journal of International Business and Cultural Studies, 4, 1-14.

Mukarromah, I., Mudjito, M., \& Purbaningrum, E. (2019). The effect of managerial skills (Conceptual, Human, and Technical) of headmasters to the effectiveness of Islamic Senior High Schools in Jombang District. International Journal for Educational and Vocational Studies, 1(6), 539-544.

Murtiningsih, M., Kristiawan, M., \& Lian, B. (2019). The correlation between supervision of headmaster and interpersonal communication with work ethos of the teacher. European Journal of Education Studies, 6(1), 246-256.

Mutohar, P. M. (2013). Manajemen mutu sekolah: Strategi peningkatan mutu dan daya saing Lembaga Pendidikan Islam [School quality management: Strategies for improving the quality and competitiveness of Islamic Education Institutions]. Jogjakarta: Ar-Ruzz Media.

Mutohar, P.M., \& Jani, H. (2020). Mutu dan Daya Saing Pendidikan Tinggi Islam: Tinauan Kepemimpinan, Layanan, Budaya Akademik, dan Kinerja [Quality and Competitiveness of Islamic Higher Education: Review of Leadership, Service, Academic Culture, and Performance]. Tulungagung: Penerbit Cahaya Abadi.

Mondy, R. W. (1990). Lecture Notes and Experimental Exercises for Management and Organizational Behavior. USA: Allyn and Bacon. 


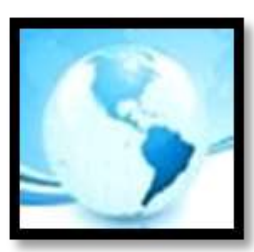

\section{MALAYSIAN ONLINE JOURNAL OF EDUCATIONAL MANAGEMENT (MOJEM)}

Motwani, J., \& Kumar, A. (1997). The need for implementing total quality management in education. International Journal of Educational Management, 11(3), 131-135.

Naor, M., Goldstein, S. M., Linderman, K. W., \& Schroeder, R. G. (2008). The role of culture as a driver of quality management and performance: Infrastructure versus core quality practices. Decision Sciences, 39(4), 671702.

Neagley, R. L., \& Evans, N. D. (1980). Handbook for effective supervision of instruction. Englewood Cliffs, N.J. : Prentice-Hall.

Nemet, M. B. (2017, January). Correlation between teachers' social and pedagogical competences and school culture. In 42nd ATEE Conference 2017-Changing Perspectives and Approaches in Contemporary Teaching.

Newmann, F. M., \& Wehlage, G. G. (1995). Successful school restructuring: A report to the public and educators. Madison, WI: Center on Organization and Restructuring of Schools.

Nursikin, M. (2018). Eksistensi madrasah dan sekolah Islam sebagai Lembaga Pendidikan Islam dalam Sistem Pendidikan Nasional (Studi Kasus di MAN Yogyakarta III dan SMA Muhammadiyah 1 Yogyakarta) [The existence of madrasas and Islamic schools as Islamic Education Institutions in the National Education System (Case Study in MAN Yogyakarta III and Muhammadiyah 1 Yogyakarta High School)]. Istawa: Jurnal Pendidikan Islam, 3(1), 27-58.

Nwambam, A. S., \& Eze, P. I. (2017). Place of instructional supervision in enhancing public primary school teachers' effectiveness. Educational Research and Reviews, 12(7), 467-472.

Ohlson, M., Swanson, A., Adams-Manning, A., \& Byrd, A. (2016). A culture of success-examining school culture and student outcomes via a performance framework. Journal of Education and Learning, 5(1), 114-127.

Oke, E. B. (2016). Influence of early childhood instructional supervision on caregivers' effectiveness in Federal Capital Territory Centers, Abuja Nigeria. International Journal for Cross-Disciplinary Subjects in Education (IJCDSE), 7(1), $2682-2692$.

Ouchi, W. G., \& Cuchi, W. G. (1981). Theory Z: How American business can meet the Japanese challenge (13 ${ }^{\text {th }}$ ed.). Reading, MA: Addison-Wesley.

Owens, R. G. (1995). Organizational behaviours in education. Boston: Allyn and Bacon, Inc.

Pichler, S. (2019). Performance appraisal reactions: A review and research agenda. In L. A. Steelman \& J. R. Williams (Eds.), Feedback at Work (pp. 75-96). USA: Springer, Cham.

Pont, B., Nusche, D., \& Moorman, H. (2008). Improving school leadership. Volume 1: Policy and practice. Australia: OECD Publications.

Primayana, K. H. (2016). Manajemen sumber daya manusia dalam peningkatan mutu pendidikan di Perguruan Tinggi [Human resource management in improving the quality of education in Higher Education]. Jurnal Penjaminan Mutu, 1(2), 7-15.

Purba, E. M., Ambarita, B., \& Siagian, S. (2018). The influence of organizational culture, principal managerial skills, job satisfaction on teacher's commitment to State Junior High Pematang Siantar School [The influence of organizational culture, principal managerial skills, job satisfaction on teacher's commitment to State Junior High Pematang Siantar School]. IJSRSET, 4(4), 309-317.

Rauf, P. A., Ali, S. K. S., Aluwi, A., \& Noor, N. A. M. (2018). The effect of school culture on the management of professional development in secondary schools in Malaysia. MOJES: Malaysian Online Journal of Educational Sciences, 2(3), 41-52.

Redding, S., \& Corbett, J. (2018). Shifting school culture to spark rapid improvement: A quick start guide for principals and their teams. Sans Francisco, CA: Center on School Turnaround at WestEd.

Renata, R., Wardiah, D., \& Kristiawan, M. (2018). The influence of headmaster's supervision and achievement motivation on effective teachers. International Journal of Scientific \& Technology Research, 7(4), 44-49.

Reynolds, D. (1993). Linking school effectiveness knowledge and school improvement practice. In C. Dimmock (Ed.), School-based management and school effectiveness. (pp. 185-200). London: Routledge.

Reynolds, D. (2018). Using school effectiveness knowledge for children with special needs-the problems and possibilities. In C. Clarck (Ed.), Towards Inclusive Schools? (pp. 109-126). London: Routledge.

Richey, R. W. (1973). Planning for Teaching: An Introduction to Education. New York: McGraw-Hill Book Company. 


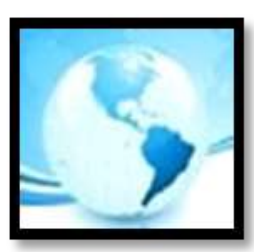

\section{MALAYSIAN ONLINE JOURNAL OF EDUCATIONAL MANAGEMENT (MOJEM)}

Richter, N. F., Cepeda-Carrión, G., Roldán Salgueiro, J. L., \& Ringle, C. M. (2016). European management research using partial least squares structural equation modeling (PLS-SEM). European Management Journal, 34(6), 589-597.

Rivai. (2004). Kepemimpinan dan perilaku organisasi [Leadership and organizational behaviours]. Jakarta: PT Raja Grafindo Persada.

Robbin, S. P. (1990). Organization theory, structure, design, and application. Nueva, Jersey: Englewood Cliffs.

Robbins, S. P., \& Judge, T. (2003). Essentials of organizational behaviours. Upper Saddle River, NJ: Prentice-Hall.

Sabancı, A., Ahmet, A., Sönmez, M. A., \& Yılmaz, O. (2016). The correlation between school managers' communication skills and school culture. International Journal of Progressive Education, 12(3), 155-171.

Sabancı, A., Şahin, A., Sönmez, M. A., \& Yılmaz, O. (2017). Views of school managers and teachers about school culture. E-International Journal of Educational Research, 8(1), 28-45.

Saleemi, N. A. (2011). Personnel management simplified (Revised \& Updated). Nairobi: ACME Press Kenya) Ltd.

Sarstedt, M., \& Cheah, J. H. (2019). Partial least squares structural equation modeling using SmartPLS: A software review. Journal of Marketing Analytics, 7(3), 196-202.

Scheerens, J., \& Creemers, B. P. (1989). Conceptualizing school effectiveness. International Journal of Educational Research, 13(7), 691-706.

Seashore Louis, K., \& Lee, M. (2016). Teachers' capacity for organizational learning: The effects of school culture and context. School Effectiveness and School Improvement, 27(4), 534-556.

Sergiovanni, T. J. (Ed.). (1982). Supervision of teaching. Alexandria, Virginia: Association for Supervision and Curriculum Development.

Sergiovanni, T., \& Starratt, R. (2006). Supervision: A redefinition. Australia: McGraw-Hill Humanities/Social Sciences/Languages.

Sihombing, N. W., Nasution, H., \& Sadalia, I. (2019). The effect of supervision and managerial competence on the principal of the job satisfaction of teachers in SMP 5 Kisaran. International Journal of Multicultural and Multireligious Understanding, 6(6), 21-29.

Silaparasetti, V., Rao, G. V. R., \& Khan, F. R. (2017). Structural equation modeling analysis using SMART PLS to assess the occupational health and safety (OHS) factors on workers' behaviours. Humanities \& Social Science Reviews, 5(2), 88-97.

Smart, K. C. (2016). The effects of leadership style on school culture and teacher effectiveness (Doctorate Dissertation, Union University). Retrieved from https://eric.ed.gov/?id=ED570007

Smircich L. (2010) Concepts of culture and organisational analysis. Administrative Science Quarterly, 28(3), 339358.

Smith, O. (2013). The spirit of the teacher. Montessori Life, 25(3), 46-49.

Steenbrink, K. A. (1991). Pesantren, madrasah, sekolah: Pendidikan Islam dalam kurun modern [Boarding schools, madrasas, schools: Islamic Education in the modern period. Jakarta: LP3ES.

Steinberg, M. P., \& Garrett, R. (2016). Classroom composition and measured teacher performance: What do teacher observation scores measure? Educational Evaluation and Policy Analysis, 38(2), 293-317.

Stolovich, H. D., \& Keeps, E. J. (1992). Handbook of human performance technology. San Francisco, Ca: Jossey-Bass.

Sudarjat, J., Abdullah, T., \& Sunaryo, W. (2015). Supervision, Leadership, and working motivation to teachers' performance. International Journal of Managerial Studies and Research (IJMSR), 3(6), 146-152.

Syomwene, A. (2018). Effective school indicators for quality curriculum implementation process. African Journal of Education, Science, and Technology, 4(3), 150-159.

Taylor, E. S., \& Tyler, J. H. (2012). The effect of evaluation on teacher performance. American Economic Review, 102(7), 3628-51.

Thair, M., \& Treagust, D. F. (2003). A brief history of a science teacher professional development initiative in Indonesia and the implications for centralized teacher development. International Journal of Educational Development, 23(2), 201-213.

Ujiarto, T., Rusdarti, R., Rifai, R. C., \& Raharjo, T. J. (2017). Effect of the school principal's management, academic supervision, organizational culture, and work motivation to the teacher's professionalism. The Journal of Educational Development, 5(3), 414-424. 


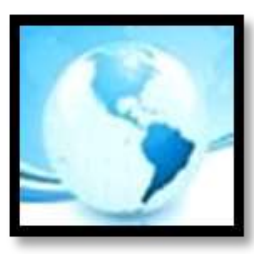

\section{MALAYSIAN ONLINE JOURNAL OF EDUCATIONAL MANAGEMENT (MOJEM)}

Vijayabanu, C., \& Therasa, C. (2016). The leveraging effect of supervisory competencies towards the performance in Indian manufacturing group: A Structural Equation Modelling Approach. Journal of Organisational Transformation \& Social Change, 13(3), 220-234.

Voorhees, C. M., Brady, M. K., Calantone, R., \& Ramirez, E. (2016). Discriminant validity testing in marketing: an analysis, causes for concern, and proposed remedies. Journal of the Academy of Marketing Science, 44(1), 119-134.

Wachira, F. M., Gitumu, M., \& Mbugua, Z. (2017). Effect of principals' leadership styles on teachers' job performance in public secondary schools in Kieni West Sub-County. International Journal of Humanities \& Social Science Invention, 6(8), 77-86.

Waddell, D., Devine, J., Jones, G. R., \& George, J. M. (2007). Contemporary management. New York: Mc Graw Hill Irwin.

Wang, L., Demas, A., Quota, M. B. N., \& Prouty, B. (2019). Developing effective school leadership. In S. E. T. ElKogali \& C. Krafft (Eds.), Expectations and Aspirations: A New Framework for Education in the Middle East and North Africa (pp. 225-234). Retrieved from https://elibrary.worldbank.org/doi/pdf/10.1596/978-14648-1234-7_ch10

Waterman, R. H., \& Peters, T. J. (1982). In search of excellence: Lessons from America's best-run companies. New York: Harper \& Row.

Wong, K. K. (2019). Mastering partial least squares structural equation modeling (PLS-SEM) with SmartPLS in 38 hours. Bloomington, Indiana: Iuniverse, Inc.

Zahed-Babelan, A., Koulaei, G., Moeinikia, M., \& Sharif, A. R. (2019). Instructional leadership effects on teachers' work engagement: roles of school culture, empowerment, and job characteristics. CEPS Journal, 9(3), 137156. 